\title{
WET-PROCESS ENAMELS FOR CAST IRON.
}

\author{
By R. R. Danielson and H. P. Reinecker.
}

ABSTRACT.

Scope of investigation.-This paper deals with an investigation of vitreous enamels to be applied to cast iron by the wet process, both with and without ground coats. About I30 different enamels have been applied to approximately 900 castings in this laboratory. Fifteen of the more promising compositions have been investigated further at a stove factory by a representative of the bureau, and in this work some 320 typical stove castings have been enameled. The effect of variations in the compositions of ground coats, white cover enamels, and both colored and white single-coat enamels have been studied. Suitable technic for the preparation and application of the enamels is discussed.

\section{CONCLUSIONS.}

Ground coats.- Sintering of the ground coats is recommended to develop best adherence to the iron. Suitable mill batches consist of roo parts of frit and I5 parts of clay, by weight, or Io parts each of clay and flint to Ioo parts of frit.

White cover enamels. - These may be smelted in the usual manner. Suitable mill batches are roo parts of frit, 8 of tin oxide, and 5 of clay. The cover enamels must not be too refractory for the ground coat or blistering will result.

Single-coat colored enamels.-Mill additions for these enamels are 4 per cent of clay and the necessary amounts of color oxides.

Single-coat white enamels.-These are not as satisfactory in opacity as the white enamels applied over a ground coat. Mill additions must be low-4 per cent each of clay and tin oxide.

General.-Boric oxide and cryolite tend to cause crawling of the enamels. Lead oxide promotes better adherence of enamels, although it decreases their firing range. Sodium oxide also decreases their firing range and causes blistering. Boric oxide increases firing range. Satisfactory compositions are given in the conclusions from the studies of the various types of enamels.

\section{CONTENTS.}

PART. I. WET-PROCESS ENAMELS WITH THE USE OF A GROUND COAT.

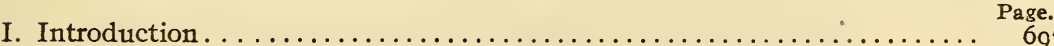

II. Preparation and application of enamels.

III. Experimental study of ground coats..........

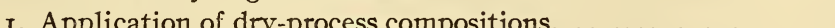

2. Effect of varying mill additions. .....................

3. Effect of varying frit compositions.................. 702

(a) Replacement of flint by lead oxide............... 705

(b) Replacement of lead oxide by boric oxide........... 705

(c) Replacement of lead oxide by sodium oxide......... 705

(d) Replacement of flint by feldspar................ 705

(e) Replacement of flint by sodium oxide............. 706

(f) Replacement of boric oxide by sodium oxide......... 706

(g) Replacement of flint by boric oxide............. 706

4. Conclusions from study of ground coats............... 706 
IV. Experimental study of cover enar

r. Types of defects encountered...

.

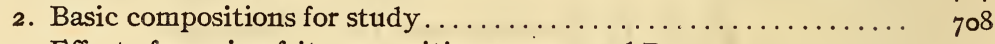

3. Effect of varying frit compositions on enamel R-I......... 7 rI

(a) Replacement of feldspar by boric oxide............ 7 II

(b) Replacement of feldspar by lead oxide............ 7 rr

(c) Replacement of lead oxide by boric oxide.......... $7^{\mathrm{r} 2}$

(d) Replacement of feldspar by cryolite............. 7 ז 3

4. Effect of varying frit compositions on enamel $\mathrm{R}-7 \ldots \ldots \ldots \ldots \ldots, 7^{\mathrm{r}} 3$

(a) Replacement of boric oxide by feldspar............. $7^{\text {I } 4}$

(b) Replacement of lead oxide by feldspar............ $7^{\mathrm{I} 4}$

(c) Replacement of boric oxide by lead oxide........... . 7I 7

(d) Replacement of feldspar by cryolite............. $7 \mathrm{r} 7$

(e) Replacement of boric oxide by cryolite............ $7 \mathrm{r} 7$

V. General conclusions from study of enamels with ground coats......... $7^{1} 8$

\section{PART II. WET-PROCESS ENAMELS WITHOUT THE USE OF A GROUND COAT.}

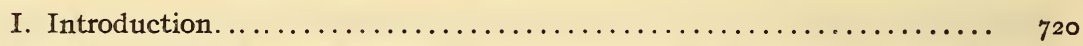

II. Preparation of enamels. . . . .

III. Study of single-coat colored enamels.......................... $7^{2 \text { I }}$

I. Basic compositions for study . . . . . . $\ldots \ldots \ldots \ldots \ldots \ldots \ldots, \quad 72 I$

2. Effect of varying the composition of enamel $\mathrm{Rg}-7 \ldots \ldots \ldots \ldots, 72 \mathrm{I}$

(a) Replacement of flint by cryolite............... $72 \mathrm{I}$

(b) Replacement of flint by lead oxide............. $72 \mathrm{I}$

(c) Replacement of flint by boric oxide............ 724

3. Effect of varying compositions based on enamel $\mathrm{Rg}-4 \mathrm{a} \ldots \ldots \ldots \quad 725$

(a) Replacement of feldspar by cryolite............. 725

(b) Replacement of boric oxide by lead oxide......... 725

IV. Conclusions from study of single-coat colored enamels............ $7^{2} 5$

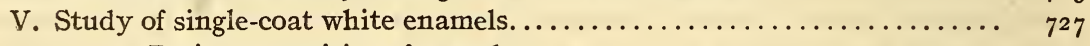

r. Basic compositions for study ................... 727

2. Effect of varying compositions..................... $\quad 7^{27}$

(a) Replacement of feldspar by cryolite............. 727

(b) Replacement of feldspar by zinc oxide........... 727

(c) Replacement of feldspar by antimony oxide......... 728

(d) Replacement of feldspar by zirconium oxide........ $73^{\mathrm{I}}$

(e) Replacement of feldspar by oxides of zirconium and antimony............................. $73 \mathrm{r}$

(f) Replacement of feldspar by zirconium oxide and cryolite. . $73^{\mathrm{I}}$

(g) Replacement of feldspar by antimony oxide and cryolite. . 73I

(h) Replacement of feldspar and sodium oxide by fluorspar and

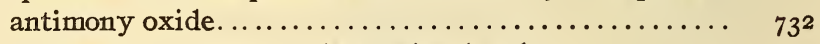

(i) Additions of tin oxide to the smelter batch.......... 732

(j) Replacements of boric oxide by cryolite........... $73^{2}$

(k) Additions of zirconium silicate to enamels.......... 732

VI. Conclusions from study of single-coat white enamels.............. 734

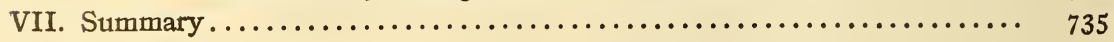




\section{PART I.-WET-PROCESS ENAMELS WITH THE USE OF A GROUND COAT.}

\section{INTRODUCTION.}

Wet-process enameling for cast iron has become of great importance within the last few years, particularly in the stove industry. This is undoubtedly due to the fact that small castings required for stoves can be handled in greater volume and at less cost by this process than by the dry process. Less skilled labor is required for manipulation, and the method lends itself readily to the enameling of irregularly shaped castings.

Very little has been published regarding this method of enameling, although it has been used for some time in the manufacture of cast-iron cooking ware. The various treatises on the subject of enameling either make no reference to, or are so vague in their treatment of, the wet process for enameling of cast iron that they are of no help to those interested in the development of suitable compositions and technic.

It may generally be stated that the strength of enamels is inversely proportional to the thickness of the coat when the properly balanced composition is used. The heavy coats of enamel as used in the dry process are liable to chip, particularly on sharp edges, when subjected to impact. The wet process tends to overcome this difficulty, as it is possible to apply the enamel in much thinner coats.

Two distinct types of wet-process cast-iron enamels are commonly used, two or three coat process in connection with the use of a ground coat, and one or two coat process without the use of a ground coat, using one composition for both coats. This paper will treat of both types, the development of ground coats, and white cover enamels being considered first.

The method of application of this type of enamel is similar to that for steel enameling, as the ground or first coat is fired and allowed to cool before the cover is applied. The dry process, as generally used in the enameling of bathtubs and sanitary ware, necessitates the sieving on of the dry, powdered cover enamel before the ground-coated ware has cooled and the return of the casting to the furnace to gloss over the enamel, thus making it impossible to fire more than a limited number of pieces at a time.

Since it was believed that ground coats were as important as the covers, the first principal work has been in the development 
of suitable compositions for such grounds. The basis of this work consisted of a number of typical ground coats now in use for the dry process. In order to obtain an enamel of the proper physical properties, the above procedure was considered advisable.

In studying cover enamels the same procedure was employed, several enamels which had given good results in commercial practice when used by the dry process being selected as the basis for the studies. This work consisted of noting the effects of variation in composition and heat treatment.

In studying the three-coat wet-process enamels the methods of preparing the enamels and the technic employed were based on the conclusions drawn from previous preliminary studies.

\section{PREPARATION AND APPLICATION OF ENAMELS.}

In the preliminary study the ground coats were prepared by weighing out the materials in 5-pound batches, mixing thoroughly and smelting in crucibles to the same degree as in the preparation of ground coats for sheet steel. It was soon found that the ground coats prepared by this method had very poor adherence, so the sintering method was resorted to. The latter method gave excellent results and was adopted, therefore, in the preparation of all ground coats used in this investigation. The materials were placed in crucibles and fired in a kiln to approximately $975^{\circ} \mathrm{C}$. $\left(\mathrm{I}, 775^{\circ} \mathrm{F}\right.$.) over a period of two hours. Upon cooling the frits were broken from the crucibles and crushed in a jaw crusher to a size suitable for grinding in ball mills.

The sintering method undoubtedly prevents the volatilization of the fluxes and also results in a ground coat having greater strength than that obtained in the melting of the materials to a glassy frit. These results have been checked with a large number of varying compositions, and even in the case of the more fusible ground coats the sintering method gave far better adherence, although it is quite possible that satisfactory results may be obtained in the smelting of certain other compositions.

The cover coats were prepared in the usual way by smelting, except that the customary content of tin oxide was reserved for the mill addition. This consisted of 8 per cent tin oxide and 5 per cent Johnson-Porter Tennessee ball clay, with the necessary amount of water to form a slip for spraying.

The cast-iron specimens for test were corner fittings and oval disks used in the manufacture of enameled stoves. They made ideal samples, as they had a number of curved surfaces and sharp 
corners which would accentuate poor adherence of the enamel. The castings were prepared for enameling by annealing at temperatures approximating $815^{\circ} \mathrm{C}$. $\left(\mathrm{I}, 500^{\circ} \mathrm{F}\right.$.). They were then sand-blasted with a mixture of about 80 per cent sand and 20 per cent crushed steel shot.

The cleaned castings were coated with a light application of the various ground coats by means of an air spray. They were then dried thoroughly and fired in an electric furnace at temperatures varying from 760 to $815^{\circ} \mathrm{C}$. $\left(\mathrm{I}, 400\right.$ to $\mathrm{I}, 500^{\circ} \mathrm{F}$.). The time of firing varied from 5 to Io minutes, depending upon the particular ground coat and the type of casting used. After the firing and cooling of the ground-coat enamel the castings were coated with the cover enamel by spraying and again thoroughly dried. It is well to emphasize at this point the necessity of thorough drying if crawling of the enamel is to be avoided. The cover coats were fired at 730 to $760^{\circ} \mathrm{C}$. $\left(\mathrm{I}, 350\right.$ to $\mathrm{I}, 400^{\circ} \mathrm{F}$.), the time of firing varying from 5 to Io minutes, depending on the refractoriness of the composition.

\section{EXPERIMENTAL STUDY OF GROUND COATS.}

To note the working qualities of the ground coats in respect to the cover coats, especially as to adherence and texture, enamels $\mathrm{R}-\mathrm{I}$ (Table $4 \mathrm{~A}$ ) and $\mathrm{R}-7$ (Table $5 \mathrm{~A}$ ) were used with each ground coat. $R-I$ was a medium refractory enamel, while $R-5$ was comparatively soft.

\section{APPLICATION OT DRY-PROCESS COMPOSITIONS.}

In Table I are shown four basic ground-coat compositions giving the batch weights and mili additions for each composition. These are typical compositions of ground coats used for dry-process enameling of cast iron. ${ }^{1} \quad \mathrm{Rg}-\mathrm{I}$ is representative of the flint type with a considerable amount of raw clay in the mill mix. $\mathrm{Rg}-2$ is a combined flint and feldspar type, a fairly refractory type, with small additions of clay and cobalt oxide in the mill batch. In composition $\mathrm{Rg}-3$ is shown a combination of two fusible frits containing large amounts of lead oxide, both the feldspar and flint types being represented. The mill additions consist of medium quantities of clay, flint, and feldspar. Ground coat $\mathrm{Rg}-4$ differs from the other compositions in this series, as it has a comparatively high content of boric acid and feldspar. The mill additions consist of a medium amount of clay and a small percentage of cobalt oxide.

1 H. F. Staley, B. S. Tech. Paper 142, pp. 79-82. 
TABLE 1.-Ground Coats for Wet-Process Cast-Iron Enamels.

[Batch composition of Frits.]

FRITS.

\begin{tabular}{|c|c|c|c|c|c|}
\hline \multirow{2}{*}{ Composition. } & \multirow{2}{*}{ Rg-1. } & \multirow{2}{*}{$\mathrm{Rg}-2$} & \multicolumn{2}{|c|}{$\mathrm{Rg}-3$} & \multirow{2}{*}{$\mathbf{R g}-4$} \\
\hline & & & (a) & (b) & \\
\hline 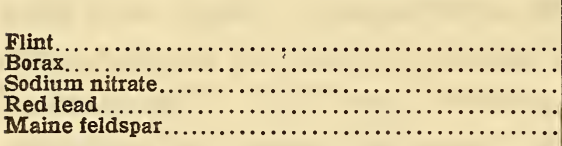 & $\begin{array}{r}\text { Per cent. } \\
57.4 \\
30.2 \\
5.7 \\
6.7 \\
\ldots \ldots . .\end{array}$ & $\begin{array}{r}\text { Per cent. } \\
24.5 \\
33.3 \\
\ldots \ldots .1 .6 \\
38.6\end{array}$ & $\begin{array}{r}\text { Per cent. } \\
\cdots \cdots \\
20.5 \\
3.6 \\
22.3 \\
53.6\end{array}$ & \begin{tabular}{|r} 
Per cent. \\
42.0 \\
25.3 \\
5.1 \\
27.6 \\
$\ldots . .$.
\end{tabular} & $\begin{array}{r}\text { Per cent. } \\
\cdots \cdots \\
48.3 \\
3.5 \\
1.7 \\
46.5\end{array}$ \\
\hline Total..... & 100.0 & 100.0 & 100.0 & 100.0 & 100.0 \\
\hline
\end{tabular}

MIII BATCHES.

\begin{tabular}{|c|c|c|c|c|}
\hline 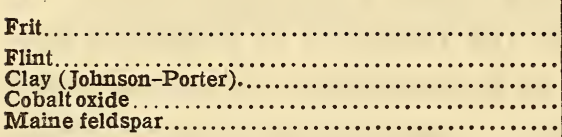 & $\begin{array}{r}100 \\
69 \\
36 \\
\ldots \ldots \\
\cdots \cdots\end{array}$ & $\begin{array}{c}100 \\
\ldots \ldots \ldots \\
6.33 \\
0 . \cdots \cdots\end{array}$ & 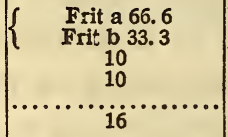 & $\begin{array}{r}100 \\
\cdots \cdots \\
15 \\
0.3 \\
\ldots \ldots \ldots\end{array}$ \\
\hline
\end{tabular}

Although these ground coats had given very good results when used by the dry process, it was noted that when applied by the wet process there was considerable variation in such properties as adherence, texture, etc., both in respect to the ground coat and the cover enamel.

Apparently the best results were obtained with $\mathrm{Rg}-\mathrm{I}$. This ground coat gave fair adherence, but the most desirable feature was the comparative freedom from pinholes in the cover enamel.

Ground coat Rg-2 adhered poorly to the iron, showing that this type of coating did not have the proper physical properties to withstand the stresses set up in cooling without the use of a cover for protection. It also had a short firing range, so that there was a tendency for the cover enamel to develop pinholes.

With ground coat $\mathrm{Rg}-3$ fairly good results were obtained, approaching those of $\mathrm{Rg}-\mathrm{I}$, although there was a tendency to develop fine pinholes, especially when slightly overfired.

When the frit compositions $(a)$ and $(b)$ of $\mathrm{Rg}-3$ were combined to give a single frit of the same theoretical composition, the results differed very much. The resulting ground coat had poor adherence, showing that the physical condition of the enamel is fully as important as its chemical composition.

Composition $\mathrm{Rg}-4$, a feldspar ground coat, had very good adherence but had a decided tendency to form pinholes, which may have been due to its greater fusibility as compared with the cover coats. 


\section{EFFECT OF VARYING MILI ADDITIONS.}

Since $\mathrm{Rg}-\mathrm{I}$, with a high content of raw mill additions, had fairly good adherence and the covers applied to this ground gave the best results as to texture and capacity, it was decided to study the effect of varying mill additions. Inasmuch as $\mathrm{Rg}-\mathrm{I}$ contained a considerable amount of flint and clay, it was planned to study the effect of replacing the flint by feldspar and clay and also the replacement of clay by flint and feldspar, simply retaining enough clay to keep the frit in suspension after milling. In this procedure it was hoped that a composition might be developed which would have good adherence as well as the other desired qualities. In making these substitutions the ratio of fusibilities, as suggested for various enamel refractories by $\mathrm{Coe}^{2}$ in his work on ground coats for cast iron, was used. Coe gives the following ratio:

40 parts of clay $=66$ parts of flint $=100$ parts of feldspar and the substitutions were made in $\mathrm{Rg}-\mathrm{I}$ on this basis.

In series I, Table 2, ground coat IB- $\mathrm{Rg}-\mathrm{I}$ has the flint addition in the mill batch of $\mathrm{Rg}-\mathrm{I}$ replaced by clay in the ratios given by Coe. This should result in a composition with the same refractoriness as $\mathrm{Rg}-\mathrm{I}$. To the remaining members of the series clay has been added or subtracted in units of 15.5 parts.

TABLE 2.-Effect of Variations in Mill Additions.

[Frit constant, $100 \mathrm{~g}$. ]

\begin{tabular}{|c|c|c|c|c|c|c|}
\hline \multirow{3}{*}{ Ground coat number. } & \multicolumn{5}{|c|}{ Mill additions. } & \multirow[b]{3}{*}{$\begin{array}{c}\text { Cover } \\
\text { pinholes. }\end{array}$} \\
\hline & \multirow[b]{2}{*}{ Clay. } & \multirow[b]{2}{*}{ Flint. } & \multirow[b]{2}{*}{$\begin{array}{l}\text { Feld- } \\
\text { spar. }\end{array}$} & \multicolumn{2}{|l|}{ Adherence. } & \\
\hline & & & & Ground coat. & $\begin{array}{l}\text { After } \\
\text { applying } \\
\text { cover. }\end{array}$ & \\
\hline 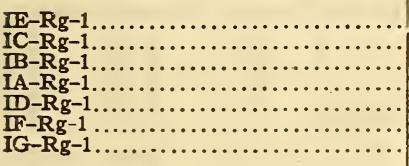 & $\begin{array}{r}108.5 \\
93.0 \\
77.5 \\
62.0 \\
46.5 \\
31.0 \\
15.5\end{array}$ & $\begin{array}{l}\cdots \cdots \cdots \\
\cdots \cdots \cdots \\
\cdots \cdots \\
\cdots \cdots \\
\cdots \cdots \\
\cdots \cdots\end{array}$ & $\begin{array}{l}\cdots \cdots \cdots \\
\cdots \cdots \cdots \\
\cdots \cdots \\
\cdots \cdots \cdots \\
\cdots \cdots \cdots \\
\cdots \cdots\end{array}$ & 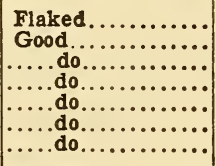 & 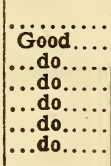 & $\begin{array}{l}\text { None. } \\
\text { Do. } \\
\text { Do. } \\
\text { Few. } \\
\text { Do. } \\
\text { Do. }\end{array}$ \\
\hline 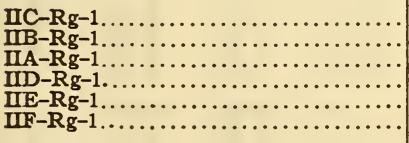 & $\begin{array}{l}6.0 \\
6.0 \\
6.0 \\
6.0 \\
6.0 \\
6.0\end{array}$ & $\begin{array}{r}114.0 \\
120.0 \\
96.0 \\
73.0 \\
48.0 \\
24.0\end{array}$ & $\begin{array}{l}\cdots \cdots \cdots \\
\cdots \cdots \cdots \\
\cdots \cdots \cdots \\
\cdots \cdots \cdots \\
\cdots \cdots \cdots \\
\cdots \cdots\end{array}$ & $\begin{array}{l}\text { Flaked } \ldots \ldots \ldots \ldots \\
\ldots \ldots \text { do } \ldots \ldots \ldots \ldots \ldots \\
\text { Chipped on edge... } \\
\text { Good } \ldots \ldots \ldots \ldots \ldots \ldots\end{array}$ & 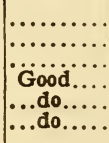 & $\begin{array}{c}\text { None. } \\
\text { Many. } \\
\text { De. }\end{array}$ \\
\hline 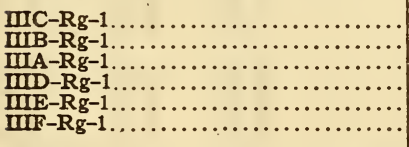 & $\begin{array}{l}6.0 \\
6.0 \\
6.0 \\
6.0 \\
6.0 \\
6.0\end{array}$ & $\begin{array}{l}\cdots \cdots \cdots \\
\cdots \cdots \cdots \\
\cdots \cdots \cdots \\
\cdots \cdots \cdots \\
\cdots \cdots\end{array}$ & $\begin{array}{r}216.0 \\
180.0 \\
144.0 \\
108.0 \\
72.0 \\
36.0\end{array}$ & 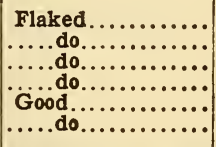 & 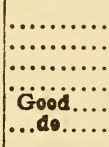 & $\begin{array}{l}\text { Bew. } \\
\text { Do. }\end{array}$ \\
\hline
\end{tabular}

${ }^{2}$ Coe, J. H., Compositions of commercial ground coats for cast-iron enamels, Trans. Am. Ceram. Soc., 13 , p. 53 I.

$60900^{\circ}-23-2$ 
Table 2 shows very clearly that with the increase of raw additions in the mill batch the adherence is not satisfactory, except in series I, where several compositions with a comparatively high clay content had good adherence. Later these were found to be undesirable as commercial compositions because the results were not consistent over a large number of trials, there being a tendency for chipping to develop in some cases. In series 2 and 3 with flint or feldspar substituted for clay the adherence was very poor, except where the additions were small. It will, therefore, be noted that flint and feldspar are poor substitutes for clay in the mill additions for ground coats, as they evidently detract from the adherent quality of the enamel.

\section{EFFECT OF VARYING FRIT COMPOSITIONS.}

Since it was concluded that an excessive amount of raw material in the mill batch was detrimental to the desired results, it was decided to make a study of the effect of variation in the composition of the frit, using 15 per cent of clay in the mill batch, approximately the maximum amount consistently giving proper adherence. Ground coat $R g-I$ was taken as a basis for this work. The different substitutions were made within the limits of workable ground coats. The latter must necessarily have the correct physical properties to permit them to undergo three distinct firings without blistering.

The theoretical melted compositions and batch weights of the 2 I ground coats studied are given in Table $3, \mathrm{~A}$ and $\mathrm{B}$.

TABLE 3 A.-Ground Coats of Series 3.

[Melted Composition of Frits.]

\begin{tabular}{|c|c|c|c|c|c|}
\hline Ground coat number. & Flint. & Feldspar. & $\mathrm{B}_{2} \mathrm{O}_{3}$. & $\mathrm{Na}_{2} \mathrm{O}$. & PbO. \\
\hline 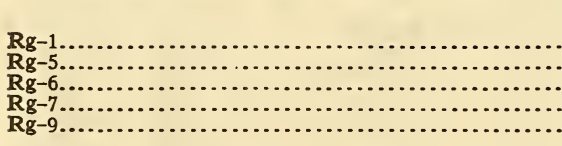 & $\begin{array}{r}\text { Per cent. } \\
69.90 \\
73.50 \\
66.30 \\
62.70 \\
\ldots . . . . .\end{array}$ & \begin{tabular}{|} 
Per cent. \\
\hdashline$\ldots$ \\
\hdashline$\ldots$ \\
\hdashline$\ldots$ \\
104.80 \\
\end{tabular} & $\begin{array}{r}\text { Per cent } \\
13.57 \\
13.57 \\
13.57 \\
13.57 \\
13.57\end{array}$ & $\begin{array}{r}\text { Per cent. } \\
8.53 \\
8.53 \\
8.53 \\
8.53 \\
8.53\end{array}$ & $\begin{array}{r}\text { Per cent. } \\
8.00 \\
4.40 \\
11.60 \\
15.20 \\
8.00\end{array}$ \\
\hline 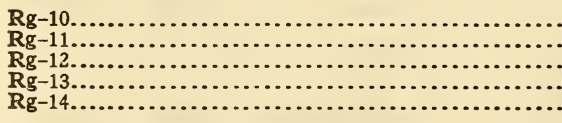 & $\begin{array}{r}34.90 \\
34.90 \\
34.90\end{array}$ & $\begin{array}{l}52.40 \\
87.40 \\
44.00 \\
69.90 \\
34.90\end{array}$ & $\begin{array}{l}13.57 \\
13.57 \\
13.57 \\
13.57 \\
13.57\end{array}$ & $\begin{array}{l}8.53 \\
8.53 \\
8.53 \\
8.53 \\
8.53\end{array}$ & $\begin{array}{l}8.00 \\
8.00 \\
8.00 \\
8.00 \\
8.00\end{array}$ \\
\hline 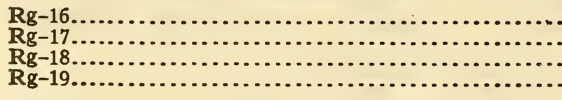 & $\begin{array}{l}69.90 \\
69.90 \\
69.90 \\
69.90\end{array}$ & 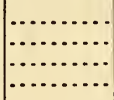 & $\begin{array}{r}21.57 \\
17.57 \\
9.57 \\
13.57\end{array}$ & $\begin{array}{r}8.53 \\
8.53 \\
8.53 \\
16.53\end{array}$ & $\begin{array}{r}4.00 \\
12.00 \\
\ldots . . .\end{array}$ \\
\hline $\begin{array}{l}\mathbf{R g}-20 \ldots \ldots \\
\mathbf{R g}-21 \ldots \ldots \\
\mathbf{R g}-22 \ldots \\
\mathbf{R g}-23 \ldots \ldots\end{array}$ & $\begin{array}{l}69.90 \\
69.90 \\
65.90 \\
61.90\end{array}$ & $\mid \begin{array}{ll} \\
\cdots \cdots \cdots \\
\cdots \cdots\end{array}$ & $\begin{array}{l}13.57 \\
13.57 \\
13.57 \\
13.57\end{array}$ & $\begin{array}{r}12.53 \\
4.53 \\
12.53 \\
16.53\end{array}$ & $\begin{array}{r}4.00 \\
12.00 \\
8.00 \\
8.00\end{array}$ \\
\hline $\begin{array}{l}\mathbf{R g}-24 \\
\mathbf{R g}-25 \\
\mathrm{Rg}-26 \\
\mathbf{R g}-27 \ldots \ldots\end{array}$ & $\begin{array}{l}69.90 \\
69.90 \\
66.30 \\
62.70\end{array}$ & $\begin{array}{ll}\cdots \cdots \cdots \\
\cdots \cdots \cdots \\
\cdots \cdots \cdots\end{array}$ & $\begin{array}{r}17.57 \\
9.57 \\
17.17 \\
20.77\end{array}$ & $\begin{array}{r}4.53 \\
12.53 \\
8.53 \\
8.53\end{array}$ & $\begin{array}{l}8.00 \\
8.00 \\
8.00 \\
8.00\end{array}$ \\
\hline
\end{tabular}


TABLE 3 B.-Ground Coats of Series 3.

[Batch Composition for 100 Parts of Melted Frit.]

\begin{tabular}{|c|c|c|c|c|c|c|c|}
\hline Ground coat number. & Flint. & $\begin{array}{l}\text { Feld- } \\
\text { spar. }\end{array}$ & Borax. & $\begin{array}{l}\text { Sodium } \\
\text { nitrate. }\end{array}$ & $\begin{array}{l}\text { Soda } \\
\text { asb. }\end{array}$ & $\begin{array}{l}\text { Red } \\
\text { lead. }\end{array}$ & $\begin{array}{l}\text { Boric } \\
\text { acid. }\end{array}$ \\
\hline 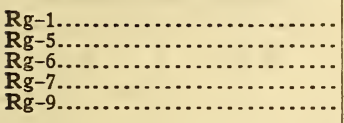 & $\begin{array}{r}69.90 \\
73.50 \\
66.30 \\
62.70 \\
\cdots\end{array}$ & $\begin{array}{r}\ldots \ldots \\
\ldots \ldots \\
\cdots \\
\cdots \\
104.80\end{array}$ & $\begin{array}{l}36.96 \\
35.96 \\
36.96 \\
36.96 \\
36.96\end{array}$ & $\begin{array}{l}6.95 \\
6.95 \\
6.95 \\
6.95 \\
6.95\end{array}$ & $\mid \begin{array}{l}\ldots \ldots \ldots \\
\cdots \ldots \ldots \\
\ldots \ldots \ldots \\
\ldots \ldots \ldots \\
\cdots \ldots \ldots \\
\cdots\end{array}$ & $\begin{array}{r}8.17 \\
5.01 \\
11.84 \\
15.51 \\
8.17\end{array}$ & $\begin{array}{l}\ldots \ldots \ldots \\
\ldots \ldots \ldots \\
\ldots \ldots \ldots \\
\ldots \ldots \ldots\end{array}$ \\
\hline 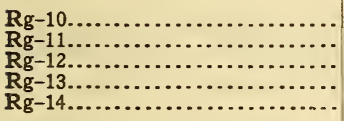 & $\begin{array}{r}34.90 \\
34.90 \\
34.90 \\
\ldots \ldots\end{array}$ & $\begin{array}{l}52.40 \\
87.40 \\
44.00 \\
69.90 \\
34.90\end{array}$ & $\begin{array}{l}36.96 \\
36.96 \\
36.96 \\
36.96 \\
36.96\end{array}$ & $\begin{array}{l}6.95 \\
6.95 \\
6.95 \\
6.95 \\
6.95\end{array}$ & \begin{tabular}{|}
$\ldots \ldots \ldots \ldots$ \\
$\ldots \ldots \ldots \ldots$ \\
$\ldots \ldots \ldots \ldots$ \\
$\ldots \ldots \ldots$ \\
$\ldots \ldots \ldots \ldots$
\end{tabular} & $\begin{array}{l}8.17 \\
8.17 \\
8.17 \\
8.17 \\
8.17\end{array}$ & $\begin{array}{l}\ldots \ldots \ldots \ldots \\
\ldots \ldots \ldots \ldots \\
\ldots \ldots \ldots \ldots \\
\ldots \ldots \ldots \ldots \\
\ldots \ldots \ldots \ldots\end{array}$ \\
\hline 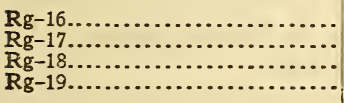 & $\begin{array}{l}69.90 \\
69.90 \\
69.90 \\
69.90\end{array}$ & 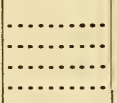 & $\begin{array}{l}36.96 \\
36.96 \\
26.07 \\
36.96\end{array}$ & $\begin{array}{l}6.95 \\
6.95 \\
6.95 \\
6.95\end{array}$ & $\begin{array}{r}3.04 \\
13.67\end{array}$ & $\begin{array}{r}4.08 \\
12.24 \\
\cdots\end{array}$ & $\begin{array}{r}14.16 \\
7.08 \\
\cdots \\
\cdots\end{array}$ \\
\hline 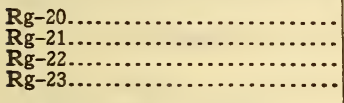 & $\begin{array}{l}69.90 \\
69.90 \\
65.90 \\
61.90\end{array}$ & $\mid \begin{array}{l}\cdots \ldots \\
\cdots \cdots \\
\cdots \cdots \\
\cdots \cdots\end{array}$ & $\begin{array}{l}36.96 \\
12.34 \\
36.96 \\
36.96\end{array}$ & $\begin{array}{l}6.95 \\
6.95 \\
6.95 \\
6.95\end{array}$ & $\begin{array}{r}6.84 \\
6.84 \\
13.67\end{array}$ & $\begin{array}{r}4.08 \\
12.24 \\
8.17 \\
8.17\end{array}$ & $\begin{array}{r}16.00 \\
\cdots \cdots\end{array}$ \\
\hline $\begin{array}{l}\mathbf{R g}-24 \ldots \ldots \ldots \\
\mathbf{R g}-25 \ldots \ldots \ldots \\
\mathbf{R g}-26 \ldots \ldots \ldots \\
\mathbf{R g}-27 \ldots \ldots \ldots \\
\end{array}$ & $\begin{array}{l}69.90 \\
69.90 \\
66.30 \\
62.70\end{array}$ & 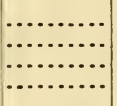 & $\begin{array}{l}12.34 \\
26.07 \\
36.96 \\
3696\end{array}$ & $\begin{array}{l}6.95 \\
6.95 \\
6.95 \\
6.95\end{array}$ & 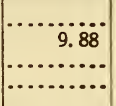 & $\begin{array}{l}8.17 \\
8.17 \\
8.17 \\
8.17\end{array}$ & $\begin{array}{r}23.06 \\
6.37 \\
12.75\end{array}$ \\
\hline
\end{tabular}

TABLE 3 C.-Effect of Varying Flint and Lead Oxide in Ground Coats.

[Constant portion melted, $13.57 \mathrm{~B}_{2} \mathrm{O}_{3}, 8.53 \mathrm{Na}_{2} \mathrm{O}$.]

\begin{tabular}{|c|c|c|c|c|c|}
\hline \multirow{3}{*}{ Ground coat number. } & \multicolumn{2}{|c|}{$\begin{array}{l}\text { Meited weights of } \\
\text { variables. }\end{array}$} & \multicolumn{3}{|c|}{ Remarks. } \\
\hline & \multirow{2}{*}{ Flint. } & \multirow{2}{*}{$\mathrm{PbO}$. } & \multirow{2}{*}{ Adherence. } & \multicolumn{2}{|c|}{$\begin{array}{c}\text { Texture of cover } \\
\text { enamels. }\end{array}$} \\
\hline & & & & $\mathbf{R}-1$ & $\mathbf{R}-5$. \\
\hline 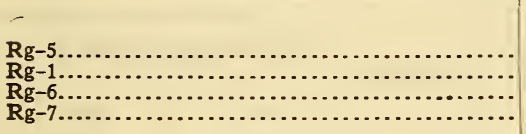 & $\begin{array}{r}\text { Per cent. } \\
73.50 \\
69.90 \\
66.30 \\
62.70\end{array}$ & \begin{tabular}{|r|} 
Per cent. \\
4.40 \\
8.00 \\
11.60 \\
15.20
\end{tabular} & 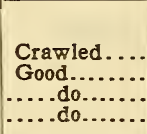 & $\begin{array}{l}\text { Good..... } \\
\text { Fair...... } \\
\text {...do...... }\end{array}$ & $\begin{array}{l}\text { Good. } \\
\text { Do. } \\
\text { Do. }\end{array}$ \\
\hline
\end{tabular}

TABLE 3 D.-Effect of Varying Boric Oxide and Lead Ozide in Ground Coats.

[Constant portion melted, 69.90 flint, $8.53 \mathrm{Na}_{2} \mathrm{O}$.]

\begin{tabular}{|c|c|c|c|c|c|}
\hline \multirow{3}{*}{ Ground coat number. } & \multicolumn{2}{|c|}{$\begin{array}{l}\text { Melted weights of } \\
\text { variables. }\end{array}$} & \multicolumn{3}{|c|}{ Remarks. } \\
\hline & \multirow{2}{*}{$\mathrm{B}_{2} \mathrm{O}_{3}$} & \multirow{2}{*}{$\mathrm{PbO}$. } & \multirow{2}{*}{ Adherence. } & \multicolumn{2}{|c|}{$\begin{array}{c}\text { Texture of cover } \\
\text { enamels. }\end{array}$} \\
\hline & & & & $\mathbf{R}-1$ & R-5. \\
\hline $\begin{array}{l}\mathbf{R g}-16 \ldots \ldots \ldots \\
\mathbf{R g}-17 \ldots \ldots \ldots \\
\mathbf{R g}-1, \ldots \ldots \ldots \\
\mathbf{R g}-18 \ldots \ldots \ldots\end{array}$ & $\begin{array}{r}\text { Per cent. } \\
21.57 \\
17.57 \\
13.57 \\
9.57\end{array}$ & $\begin{array}{r}\text { Per cent. } \\
4.00 \\
8.00 \\
12.00\end{array}$ & \begin{tabular}{|l|} 
Good....... \\
$\cdots$ do $\ldots . . .$. \\
\hdashline. do........ \\
$\cdots$ do $\ldots . .$.
\end{tabular} & 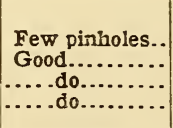 & $\begin{array}{l}\text { Good. } \\
\text { Do. } \\
\text { Do. } \\
\text { Do. }\end{array}$ \\
\hline
\end{tabular}


TABLE 3 E.-Effect of Varying Sodium Oxide and Lead Oxide in Ground Coats. [Constant portion melted, 69.90 flint, $13.57 \mathrm{~B}_{2} \mathrm{O}_{3}$.]

\begin{tabular}{|c|c|c|c|c|c|}
\hline \multirow{3}{*}{ Ground coat number. } & \multicolumn{2}{|c|}{$\begin{array}{l}\text { Melted weights of } \\
\text { variables. }\end{array}$} & \multicolumn{3}{|c|}{ Remarks. } \\
\hline & \multirow{2}{*}{$\mathrm{Na}_{2} \mathrm{O}$} & \multirow{2}{*}{ PbO. } & \multirow{2}{*}{$\begin{array}{l}\text { Adher- } \\
\text { ence. }\end{array}$} & \multicolumn{2}{|c|}{ Texture of cover enamels. } \\
\hline & & & & $\mathbf{R}-1$ & $\mathbf{R}-5$ \\
\hline 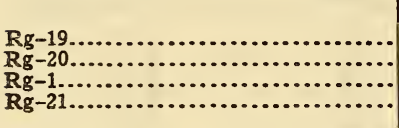 & $\begin{array}{r}\text { Per cent. } \\
16.53 \\
12.53 \\
8.53 \\
4.53\end{array}$ & $\begin{array}{r}\text { Per cent. } \\
4.00 \\
8.00 \\
12.00\end{array}$ & 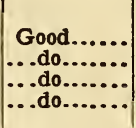 & $\begin{array}{l}\text { Many pinholes.. } \\
\text { Few pinholes.... } \\
\text { Good............ } \\
\text { Few pinholes.... }\end{array}$ & $\begin{array}{l}\text { Many pinholes. } \\
\text { Few pinholes. } \\
\text { Good. } \\
\text { Do. }\end{array}$ \\
\hline
\end{tabular}

TABLE 3 F.-Effect of Varying Flint and Feldspar in Ground Coats. [Constant portion melted, $13.57 \mathrm{~B}_{2} \mathrm{O}_{3}, 8.53 \mathrm{Na}_{2} \mathrm{O}, 8.0 \mathrm{PbO}$.]

\begin{tabular}{|c|c|c|c|c|c|}
\hline \multirow{3}{*}{ Ground coat number. } & \multicolumn{2}{|c|}{$\begin{array}{l}\text { Melted weights of } \\
\text { variables. }\end{array}$} & \multicolumn{3}{|c|}{ Remarks. } \\
\hline & \multirow{2}{*}{ Flint. } & \multirow{2}{*}{$\begin{array}{l}\text { Feld- } \\
\text { spar. }\end{array}$} & \multirow{2}{*}{$\begin{array}{l}\text { Adher- } \\
\text { ence. }\end{array}$} & \multicolumn{2}{|c|}{ Texture of cover enamel. } \\
\hline & & & & $\mathbf{R}-1$ & $\mathbf{R}-5$ \\
\hline 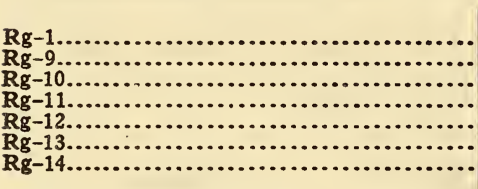 & 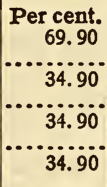 & $\begin{array}{r}\text { Per cent. } \\
104.8 \\
52.40 \\
87.50 \\
43.65 \\
69.90 \\
34.90\end{array}$ & 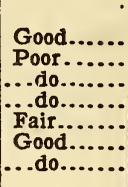 & 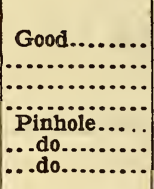 & 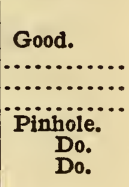 \\
\hline
\end{tabular}

TABLE 3 G.-Effect of Varying Sodium Oxide and Flint in Ground Coats.

[Constant portion melted, $13.57 \mathrm{~B}_{2} \mathrm{O}_{3}, 8.00 \mathrm{PbO}$.]

\begin{tabular}{|c|c|c|c|c|c|}
\hline \multirow{3}{*}{ Ground coat number. } & \multicolumn{2}{|c|}{$\begin{array}{l}\text { Melted weights of } \\
\text { variables. }\end{array}$} & \multicolumn{3}{|c|}{ Remarks. } \\
\hline & \multirow{2}{*}{ Flint. } & \multirow{2}{*}{$\mathrm{Na}_{2} \mathrm{O}$} & \multirow{2}{*}{ Adherence. } & \multicolumn{2}{|c|}{ Texture of cover enamel. } \\
\hline & & & & $\mathbf{R}-\mathbf{1}$ & $\mathbf{R}-\mathbf{5}$ \\
\hline $\begin{array}{l}R g-1 \ldots . \\
R g-22 \ldots \\
R g-23 \ldots\end{array}$ & $\begin{array}{r}\text { Per cent. } \\
69.90 \\
65.90 \\
61.90\end{array}$ & $\begin{array}{r}\text { Per cent. } \\
8.53 \\
12.53 \\
16.53\end{array}$ & 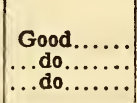 & $\begin{array}{l}\text { Good............ } \\
\text { Many pinholes.. } \\
\ldots \ldots \text { do............ }\end{array}$ & $\begin{array}{l}\text { Good. } \\
\text { Many pinholes. } \\
\text { Do. }\end{array}$ \\
\hline
\end{tabular}

TABLE 3 H.-Effect of Varying Boric Oxide and Sodium Oxide in Ground Coats. [Constant portion melted, 69.90 tlint, 8.00 PbO.]

\begin{tabular}{|c|c|c|c|c|c|}
\hline \multirow{3}{*}{ Ground coat number. } & \multicolumn{2}{|c|}{$\begin{array}{c}\text { Melted weights of } \\
\text { variables. }\end{array}$} & \multicolumn{3}{|c|}{ Remarks. } \\
\hline & \multirow{2}{*}{$\mathrm{B}_{2} \mathrm{O}_{3}$} & \multirow{2}{*}{$\mathrm{Na}_{2} \mathrm{O}$} & \multirow{2}{*}{ Adherence. } & \multicolumn{2}{|c|}{ Texture of cover enamel. } \\
\hline & & & & $\mathbf{R}-\mathbf{1}$ & $\mathbf{R}-5$ \\
\hline 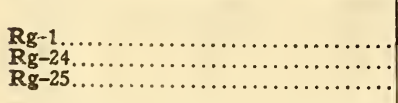 & \begin{tabular}{|r|} 
Per cent. \\
13.57 \\
17.57 \\
9.57
\end{tabular} & $\begin{array}{r}\text { Per cent. } \\
8.53 \\
4.53 \\
12.53\end{array}$ & $\begin{array}{l}\text { Good........ } \\
\ldots \text { do } \\
\ldots \text { do........... }\end{array}$ & 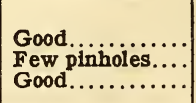 & $\begin{array}{l}\text { Good. } \\
\text { Do. } \\
\text { Few pinholes. }\end{array}$ \\
\hline
\end{tabular}


TABLE 3 I. -Effect of Varying Boric Oxide and Flint in Ground Coats.

[Constant portion meited, 8.5 $3 \mathrm{Na}_{2} \mathrm{O}, 8.00 \mathrm{PbO}$.]

\begin{tabular}{|c|c|c|c|c|c|}
\hline \multirow{3}{*}{ Ground coat number. } & \multicolumn{2}{|c|}{$\begin{array}{l}\text { Meited weights of } \\
\text { variables. }\end{array}$} & \multicolumn{3}{|c|}{ Remarks. } \\
\hline & \multirow{2}{*}{ Flint. } & \multirow{2}{*}{$\mathrm{B}_{2} \mathrm{O}_{8}$} & \multirow{2}{*}{ Adherence. } & \multicolumn{2}{|c|}{ Texture of cover enamel. } \\
\hline & & & & $\mathbf{R}-1$ & $\mathbf{R}-5$ \\
\hline $\begin{array}{l}\mathbf{R g}-1 \\
\mathbf{R g}-26 \ldots \ldots \ldots \\
\mathbf{R g}-27 \ldots \ldots \ldots \\
\end{array}$ & \begin{tabular}{|r|} 
Per cent. \\
69.90 \\
66.90 \\
62.70
\end{tabular} & $\begin{array}{r}\text { Per cent. } \\
13.57 \\
17.17 \\
20.77\end{array}$ & 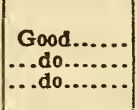 & $\begin{array}{l}\text { Good............ } \\
\text { Few pinholes.... } \\
\ldots \ldots \text { do.............. }\end{array}$ & $\begin{array}{l}\text { Good. } \\
\text { Do. } \\
\text { Few pinholes. }\end{array}$ \\
\hline
\end{tabular}

For comparison of the various compositions and their properties, it is possible to group the ground coats according to variation in the melted weights as shown in Tables $3 \mathrm{C}$ to $3 \mathrm{I}$, inclusive.

(a) REPLACEMENT OF FlinT BY LEAD OxidE.-Table $3 \mathrm{C}$ shows the effect of replacement of flint by lead oxide. The adherence of the ground coat apparently is benefitted by the replacements noted. $\mathrm{Rg}-\mathrm{I}$, with 70 per cent of flint, evidently contains the maximum amount of flint for workable ground coats. The more fusible cover enamel, $\mathrm{R}-5$, gave best results with this series of ground coats. The refractory cover, R-r, not only tended to produce blistering of the ground coat in the firing necessary to give the enamel desirable gloss and finish, but portions of the overfused ground coat were absorbed by the cover enamel, causing black specks.

(b) REPLACEMENT OF LEAD OXIDE BY BORIC OXIDE.-As a whole, the lead oxide-boric oxide series (Table 3 D) - gave very good results. However, in Rg-16 with the replacement of all the lead oxide by boric oxide, there was a tendency of the ground coat to crawl in firing and for the boric acid to crystallize from the enamel if the latter was not used very soon after milling. The crawling is undoubtedly due to the higher viscosity imparted by excessive boric oxide. This, with the crystallization noted, would indicate an excess of boric oxide in the enamel.

(c) REPLACEMENT OF LEAD OXIDE BY SODIUM OXIDE.-Replacing lead oxide with sodium oxide (Table $3 \mathrm{E}$ ) gave compositions which had a decided tendency to develop pinholes. Because of the unfavorable results further studies in this replacement were not considered.

(d) Replacement of Flint by Feldospar.-Table $3 \mathrm{~F}$ shows the effect of replacing flint by feldspar. In $\mathrm{Rg}-9$ and ro three parts of feldspar replaced two parts of flint. This was the 
fusibility relation of feldspar to flint suggested by Staley $^{3}$ for cast-iron enamels. In Rg-9 all the flint was replaced by feldspar, and in $\mathrm{Rg}-\mathrm{Io}$ half of the flint was replaced by feldspar. However, it was noted that substitutions in this ratio increased the refractoriness and resulted in a ground coat of poor adherence. The ratio of 5 to 4 was employed in replacing the flint by feldspar in $\mathrm{Rg}-\mathrm{II}$ and I2, and I to I in Rg-I3 and I4. Although these latter compositions possessed the desired fusibility, there was a decided tendency for the cover enamels applied to these grounds to form pinholes. Feldspar, because of its alumina content, undoubtedly increased the viscosity of the ground coats and might account for the tendency of these compositions high in feldspar to form pinholes, which apparently is the main objection to its substitution for flint in ground coats of the type studied.

(e) REPLACEMEINI OF Flint by SOdIUM OxIDE.-Increasing sodium oxide at the expense of flint gave poor results, as the ground coat showed many pinholes (Table $3 \mathrm{G}$ ). This also resulted in unsatisfactory covers. For this type of ground coat it is evident that the limit for sodium oxide is between 8.5 and I 2.5 per cent.

(f) Replacement of Boric Oxide By SOdium OXIdE.-When boric oxide was replaced by sodium oxide (Table $3 \mathrm{H}$ ), there was some slight formation of pinholes, but fairly good results were obtained with more refractory covers.

(g) REPLACEMENT OF FLINT BY BORIC OXIDE.-In replacing flint by boric oxide, as in Table $3 \mathrm{I}$, little change was noted, the results corresponding very closely to $\mathrm{Rg}-\mathrm{I}$. Excessive boric acid, however, tended to increase slightly the number of pinholes.

\section{CONCLUSIONS FROM STUDY OF GROUND COATS.}

Excessive addition of raw materials to the mill batch is to be discouraged. Clay and fint as mill additions give the best results, although the limits for these are fairly low. Such additions as I 5 per cent of clay or Io per cent each of clay and flint should give most satisfactory results.

Sintering of the ground coats is recommended, since melting of the materials to a glass weakens the resultant ground coat. Excessive additions of any one flux were not desirable, and the best results were obtained when sodium, lead, and boric oxides were combined in their proper proportions. Sodium oxide in excess of 
about ro per cent, on the basis of melted weights, gave rise to blistering. Boric oxide increased the firing range of the ground coats and was preferable to lead oxide in this respect, although it tended to promote crawling of those ground coats high in boric oxide if they were applied somewhat heavily. Lead oxide apparently is a very desirable flux for ground coats of this type. Substitutions of lead oxide for flint proved very satisfactory, for they improved the adherence to the castings without causing crawling, as in the case of boric oxide, or pinholing, as in the substitutions of sodium oxide for the refractories. The best ground coats, considering both adherence of the enamel and texture of the cover coats, named in order, were $\mathrm{Rg}-\mathrm{I} 6, \mathrm{I} 7, \mathrm{I}, 25$, and I8.

\section{EXPERIMENTAL STUDY OF COVER ENAMELS.}

In view of the results obtained with the cover enamels applied to the various ground coats, it was decided to make a study of the effect of varying composition in cover enamels. In order to bring out the relation of the ground coats and cover coats, the latter were applied to each of three different types of ground coat, namely, a high lead, a medium lead, and a leadless type, or $\mathrm{Rg}-7$, $\mathrm{Rg}-\mathrm{I}$, and $\mathrm{Rg}-\mathrm{I} 6$, in the latter all of the lead oxide being replaced by boric oxide. As in the ground coats the replacement of one oxide by another was adopted.

\section{TYPES OF DEFECTS ENCOUNTERED.}

In varying the compositions it was intended to bring out definitely the effect of the various constituents on adherence of the ground coat, as well as the relation of the latter to the texture and opacity of the cover enamels. In the study of the ground coats certain defects developed upon the application of cover coats which apparently were not adapted to the particular ground coats. These consisted mainly of black specks, lack of gloss, and small, incipient pinholes. The black specks had the appearance of dirt or impurities which might have been present in the raw material or which might have been collected in the preparation of the enamel; but this evidently was not the case, as the trouble was avoided when the same compositions were used by the dry process. Therefore, it was believed that the specking was due to the longer time required in melting down the cover enamels by the wet process, whereby the ground coat became overfired, and small particles of it were dissolved by the cover enamel, resulting in dark specks. 
Open pinholes on the surface of the enamels could in most cases be closed over by increasing the length of firing. There still remained, however, small incipient pinholes in the covers which could not be entirely eliminated. The lack of opacity in these cover enamels was caused by solution of the opacifying agents and volatilization of the fluorides. This naturally would be expected to occur when an unreasonable length of time of firing was required to obtain the desired texture as compared with the time for fusing these cover coats when used in the dry process.

\section{BASIC COMPOSITIONS FOR STUDY.}

It was therefore evident that in order to obtain desirable results it would be necessary to accept several basic compositions and make such substitutions in these as might be expected to develop commercial enamels.

As a basis for this work two types of enamel were chosen-R-I, a medium refractory composition; and $\mathrm{R}-7$, which was comparatively fusible. All cover enamels were smelted in the usual way and the frit was milled with 5 per cent of Johnson-Porter clay, 8 per cent tin oxide, and 45 per cent of water.

Cover composition, $\mathrm{R}-\mathrm{I}$, was a rather refractory enamel containing feldspar and quartz but comparatively low in boric oxide, while $\mathrm{R}-7$ was a more fusible composition, containing feldspar and a high content of boxic oxide but no quartz. These compositions were also selected to bring out any relation between ground costs and cover enamels; that is, whether a high boric oxide type could be expected to give better results with a ground coat high in boric oxide.

TABLE 4 A.-White Cover Enamels of Series 4.

\begin{tabular}{|c|c|c|c|c|c|c|c|c|}
\hline \multirow{2}{*}{ Enamel number } & \multicolumn{8}{|c|}{ Meited composition of frits. } \\
\hline & Feldspar. & Flint. & $\mathrm{B}_{2} \mathrm{O}_{3}$ & $\mathrm{Na}_{2} \mathrm{O}$ & $\mathrm{PbO}$. & Zno. & $\mathrm{CaF}_{2}$. & Cryolite. \\
\hline $\begin{array}{l}\mathrm{R}-1 \\
\mathrm{R}-8 \ldots \\
\mathrm{R}-9 \\
\mathrm{R}-10 \ldots \ldots \\
\mathrm{R}-11 \ldots \ldots\end{array}$ & \begin{tabular}{|r|} 
Per cent. \\
38.0 \\
33.0 \\
28.0 \\
23.0 \\
33.0 \\
3
\end{tabular} & $\begin{array}{r}\text { Per cent. } \\
12.0 \\
12.0 \\
12.0 \\
12.0 \\
12.0\end{array}$ & \begin{tabular}{|r|} 
Per cent. \\
9.0 \\
14.0 \\
19.0 \\
24.0 \\
9.0
\end{tabular} & $\begin{array}{r}\text { Per cent. } \\
8.5 \\
8.5 \\
8.5 \\
8.5 \\
8.5\end{array}$ & \begin{tabular}{|r|} 
Per cent. \\
16.0 \\
16.0 \\
16.0 \\
16.0 \\
21.0
\end{tabular} & \begin{tabular}{|r|} 
Per cent. \\
6.0 \\
6.0 \\
6.0 \\
6.0 \\
6.0
\end{tabular} & $\begin{array}{r}\text { Per cent. } \\
5.5 \\
5.5 \\
5.5 \\
5.5 \\
5.5\end{array}$ & $\begin{array}{r}\text { Per cent. } \\
5.0 \\
5.0 \\
5.0 \\
5.0 \\
5.0\end{array}$ \\
\hline $\begin{array}{l}R \\
R-12 \\
R-14 \ldots \ldots \\
R-15 \ldots \ldots \ldots \\
R-16 \ldots \ldots \ldots\end{array}$ & $\begin{array}{l}28.0 \\
23.0 \\
38.0 \\
38.0 \\
38.0\end{array}$ & $\begin{array}{l}12.0 \\
12.0 \\
12.0 \\
12.0 \\
12.0\end{array}$ & $\begin{array}{r}9.0 \\
9.0 \\
4.0 \\
14.0 \\
19.0\end{array}$ & $\begin{array}{l}8.5 \\
8.5 \\
8.5 \\
8.5 \\
8.5\end{array}$ & $\begin{array}{r}26.0 \\
31.0 \\
21.0 \\
11.0 \\
6.0\end{array}$ & $\begin{array}{l}6.0 \\
6.0 \\
6.0 \\
6.0 \\
6.0\end{array}$ & $\begin{array}{l}5.5 \\
5.5 \\
5.5 \\
5.5 \\
5.5\end{array}$ & $\begin{array}{l}5.0 \\
5.0 \\
5.0 \\
5.0 \\
5.0\end{array}$ \\
\hline 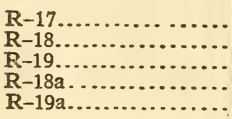 & $\begin{array}{l}38.0 \\
33.0 \\
28.0 \\
35.0 \\
30.5\end{array}$ & $\begin{array}{l}12.0 \\
12.0 \\
12.0 \\
12.0 \\
12.0\end{array}$ & $\begin{array}{r}24.0 \\
9.0 \\
9.0 \\
9.0 \\
9.0\end{array}$ & $\begin{array}{l}8.5 \\
8.5 \\
8.5 \\
8.5 \\
8.5\end{array}$ & $\begin{array}{r}1.0 \\
16.0 \\
16.0 \\
16.0 \\
16.0\end{array}$ & $\begin{array}{l}6.0 \\
6.0 \\
6.0 \\
6.0 \\
6.0\end{array}$ & $\begin{array}{l}5.5 \\
5.5 \\
5.5 \\
5.5 \\
5.5\end{array}$ & $\begin{array}{rl}5 & 0 \\
10 & 0 \\
15.0 \\
7.5 \\
12.5\end{array}$ \\
\hline
\end{tabular}


TABLE 4 B.-White Cover Enamels of Series 4.

\begin{tabular}{|c|c|c|c|c|c|c|c|c|c|c|}
\hline \multirow{2}{*}{$\begin{array}{c}\text { Enamel } \\
\text { No. }\end{array}$} & \multicolumn{10}{|c|}{ Batch compositions for 100 parts of melted frit. } \\
\hline & $\begin{array}{l}\text { Feld- } \\
\text { spar. }\end{array}$ & Flint. & Borax. & $\begin{array}{l}\text { Sodium } \\
\text { nitrate. }\end{array}$ & $\begin{array}{l}\text { Soda } \\
\text { ash. }\end{array}$ & $\begin{array}{l}\text { Red } \\
\text { lead. }\end{array}$ & $\begin{array}{c}\text { Zinc } \\
\text { oxide. }\end{array}$ & $\begin{array}{l}\text { Fluor- } \\
\text { spar. }\end{array}$ & $\begin{array}{l}\text { Cryo- } \\
\text { lite. }\end{array}$ & $\begin{array}{l}\text { Boric } \\
\text { acid. }\end{array}$ \\
\hline $\begin{array}{l}\text { R-1 } \\
\text { R-8........... } \\
\text { R-9......... } \\
\text { R-10 } \\
\text { R-11............ }\end{array}$ & $\begin{array}{l}38.0 \\
33.0 \\
28.0 \\
23.0 \\
33.0\end{array}$ & $\begin{array}{l}12.0 \\
12.0 \\
12.0 \\
12.0 \\
12.0\end{array}$ & $\begin{array}{l}24.52 \\
38.14 \\
38.14 \\
38.14 \\
24.52\end{array}$ & $\begin{array}{l}6.20 \\
6.35 \\
6.35 \\
6.35 \\
6.20\end{array}$ & 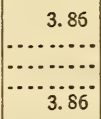 & $\begin{array}{l}16.42 \\
16.42 \\
16.42 \\
16.42 \\
21.60\end{array}$ & $\begin{array}{l}6.0 \\
6.0 \\
6.0 \\
6.0 \\
6.0\end{array}$ & $\begin{array}{l}5.5 \\
5.5 \\
5.5 \\
5.5 \\
5.5\end{array}$ & $\begin{array}{l}5.0 \\
5.0 \\
5.0 \\
5.0 \\
5.0\end{array}$ & $\begin{array}{r}8.85 \\
17.70 \\
\cdots \ldots . . .\end{array}$ \\
\hline $\begin{array}{l}\text { R-12...... } \\
\text { R-13........ } \\
\text { R-14 } \\
\text { R-15.......... } \\
\text { R-16....... }\end{array}$ & $\begin{array}{l}28.0 \\
23.0 \\
38.0 \\
38.0 \\
38.0\end{array}$ & $\begin{array}{l}12.0 \\
12.0 \\
12.0 \\
12.0 \\
12.0\end{array}$ & $\begin{array}{l}24.52 \\
24.52 \\
10.90 \\
38.14 \\
38.14\end{array}$ & $\begin{array}{l}6.20 \\
6.20 \\
6.20 \\
6.35 \\
6.35\end{array}$ & $\begin{array}{r}3.86 \\
3.86 \\
7.70 \\
\ldots . .6 . \\
.2 .6 .\end{array}$ & $\begin{array}{r}26.70 \\
31.80 \\
21.60 \\
11.30 \\
6.20\end{array}$ & $\begin{array}{l}6.0 \\
6.0 \\
6.0 \\
6.0 \\
6.0\end{array}$ & $\begin{array}{l}5.5 \\
5.5 \\
5.5 \\
5.5 \\
5.5\end{array}$ & $\begin{array}{l}5.0 \\
5.0 \\
5.0 \\
5.0 \\
5.0\end{array}$ & \begin{tabular}{l}
$\cdots \ldots . .$. \\
$\cdots \cdots . .$. \\
\hdashline$\cdots . .$. \\
8.85
\end{tabular} \\
\hline $\begin{array}{l}\text { R-17...... } \\
\text { R-18........ } \\
\text { R-19....... } \\
\text { R-18a..... } \\
\text { R-19a..... }\end{array}$ & $\begin{array}{l}38.0 \\
33.0 \\
28.0 \\
35.5 \\
30.5\end{array}$ & $\begin{array}{l}12.0 \\
12.0 \\
12.0 \\
12.0 \\
12.0\end{array}$ & $\begin{array}{l}38.14 \\
24.52 \\
24.52 \\
24.52 \\
24.52\end{array}$ & $\begin{array}{l}6.35 \\
6.20 \\
6.20 \\
6.20 \\
6.20\end{array}$ & $\begin{array}{l}3.85 \\
3.86 \\
3.86 \\
3.85\end{array}$ & $\begin{array}{r}1.03 \\
16.42 \\
16.42 \\
16.42 \\
16.42\end{array}$ & $\begin{array}{l}6.0 \\
6.0 \\
6.0 \\
6.0 \\
6.0\end{array}$ & $\begin{array}{l}5.5 \\
5.5 \\
5.5 \\
5.5 \\
5.5\end{array}$ & $\begin{array}{r}5.0 \\
10.0 \\
15.0 \\
7.5 \\
12.5\end{array}$ & 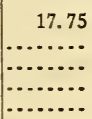 \\
\hline
\end{tabular}

TABLE 4 C.-Effect of Varying Feldspar and Boric Oride in White Cover Enamels. [Constant portion melted, $12 \mathrm{SiO}_{2}, 8.5 \mathrm{Na}_{2} \mathrm{O}, 6 \mathrm{ZnO}, 5.5 \mathrm{CaF}_{2}, 5$ cryolite.]

\begin{tabular}{|c|c|c|c|c|c|c|c|c|}
\hline \multirow{3}{*}{$\begin{array}{c}\text { Enamel } \\
\text { No. }\end{array}$} & \multicolumn{2}{|c|}{$\begin{array}{l}\text { Melted weights } \\
\text { of variables. }\end{array}$} & \multicolumn{6}{|c|}{ Remarks. } \\
\hline & \multirow{2}{*}{ Feldspar. } & \multirow{2}{*}{$\mathrm{B}_{2} \mathrm{O}_{3}$} & \multicolumn{2}{|c|}{ - $\mathbf{R g}-1$} & \multicolumn{2}{|c|}{$\mathrm{Rg}-7$. } & \multicolumn{2}{|c|}{$R g-16$} \\
\hline & & & Texture. & Opacity. & Texture. & Opacity. & Texture. & Opacity. \\
\hline $\begin{array}{l}\mathrm{R}-1 \ldots \ldots \\
\mathrm{R}-8 \ldots \ldots \\
\mathrm{R}-9 . \ldots\end{array}$ & $\begin{array}{r}\text { Per cent. } \\
38.0 \\
33.0 \\
28.0\end{array}$ & $\begin{array}{r}\text { Per cent. } \\
9.0 \\
14.0 \\
19.0\end{array}$ & $\begin{array}{l}\text { Good.......... } \\
\text { s i i g h t t }\end{array}$ & $\begin{array}{l}\text { Good } \ldots \\
\ldots \text { do...... } \\
\ldots \text {. do } \ldots . .\end{array}$ & 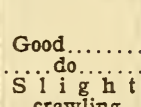 & $\begin{array}{l}\text { Good.... } \\
\text { Faido..... }\end{array}$ & 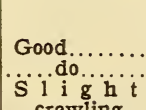 & $\begin{array}{l}\text { Good. } \\
\text { Do. } \\
\text { Do. }\end{array}$ \\
\hline $\mathbf{R}-10$ & 23.0 & 24.0 & $\begin{array}{c}\text { crawling. } \\
\text { a d I y } \\
\text { crawled. }\end{array}$ & & $\begin{array}{c}\text { B crawing. } \\
\text { a d I y } \\
\text { crawled. }\end{array}$ & & $\begin{array}{l}\text { crawing. } \\
\text { a d i y } \\
\text { crawled. }\end{array}$ & \\
\hline
\end{tabular}

TABLE 4 D.-Effect of Varying Feldspar and Lead Oxide in White Cover Enamels.

[Constant portion melted, $12 . \mathrm{SiO}_{2}, 9 \mathrm{~B}_{2} \mathrm{O}_{3}, 8.5 \mathrm{Na}_{2} \mathrm{O}, 6 \mathrm{ZnO}, 5.5 \mathrm{CaF}_{2}, 5$ cryolite.]

\begin{tabular}{|c|c|c|c|c|c|c|c|c|}
\hline \multirow{3}{*}{$\begin{array}{l}\text { Enamel } \\
\text { NNo. }\end{array}$} & \multicolumn{2}{|c|}{$\begin{array}{l}\text { Melted weights } \\
\text { of variables. }\end{array}$} & \multicolumn{6}{|c|}{ Remarks. } \\
\hline & \multirow{2}{*}{ Feldspar. } & \multirow{2}{*}{ PbO. } & \multicolumn{2}{|c|}{$\mathbf{R g}-1$. } & \multicolumn{2}{|c|}{$\mathbf{R g}-7$. } & \multicolumn{2}{|c|}{ Rg-16. } \\
\hline & & & Texture. & Opacity. & Testure. & Opacity. & Testure. & Opacity. \\
\hline $\begin{array}{l}\mathbf{R}-1 \ldots \ldots \\
\mathbf{R}-11 \ldots \ldots\end{array}$ & $\begin{array}{r}\text { Per cent. } \\
38.0 \\
33.0\end{array}$ & $\begin{array}{r}\text { Per cent. } \\
16.0 \\
21.0\end{array}$ & $\begin{array}{l}\text { Good........... } \\
\ldots \ldots \text { do....... }\end{array}$ & $\begin{array}{l}\text { Good.... } \\
\ldots \text { do..... }\end{array}$ & Good........ & $\begin{array}{l}\text { Good.... } \\
\ldots \text { do..... }\end{array}$ & Good $\ldots \ldots \ldots$ & $\begin{array}{l}\text { Good. } \\
\text { Do. }\end{array}$ \\
\hline $\begin{array}{l}\mathrm{R}-12 \ldots \\
\mathrm{R}-13 \ldots\end{array}$ & $\begin{array}{l}28.0 \\
23.0\end{array}$ & $\begin{array}{l}26.0 \\
31.0\end{array}$ & $\begin{array}{c}\text { Few pin- } \\
\text { holes. }\end{array}$ & Fair........ & ....do.......... & $\begin{array}{l}\text { Fair..... } \\
\ldots \text {. do.... }\end{array}$ & $\begin{array}{c}\text { Many pin- } \\
\text { holes. }\end{array}$ & $\begin{array}{l}\text { Do. } \\
\text { Fair. }\end{array}$ \\
\hline
\end{tabular}

$60900^{\circ}-23-3$ 
TABLE 4 E.-Effect of Varying Boric Oxide and Lead Oxide in White Cover Enamels.

[Constant portion melted, 38 feldspar, $12 \mathrm{SiO}_{2}, 8.5 \mathrm{Na}_{2} \mathrm{O}, 6 \mathrm{ZnO}, 5.5 \mathrm{CaF}_{2}, 5$ cryolite.]

\begin{tabular}{|c|c|c|c|c|c|c|c|c|}
\hline \multirow{3}{*}{$\begin{array}{l}\text { Enam- } \\
\text { el No. }\end{array}$} & \multicolumn{2}{|c|}{$\begin{array}{l}\text { Melted weights } \\
\text { of variables. }\end{array}$} & \multicolumn{4}{|c|}{ Remarks. } & 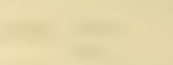 & \\
\hline & \multirow{2}{*}{$\mathrm{B}_{2} \mathrm{O}_{3}$} & \multirow{2}{*}{$\mathrm{PbO}$. } & \multicolumn{2}{|l|}{ Rg-1. } & \multicolumn{2}{|l|}{ Rg-7. } & \multicolumn{2}{|l|}{ Rg-16. } \\
\hline & & & Texture. & Opacity. & Texture. & Opacity. & Texture. & Opacity. \\
\hline $\begin{array}{l}\mathbf{R}-14 \ldots \\
\mathbf{R}-1 \ldots . . \\
\mathbf{R}-15 \ldots \\
\mathbf{R}-16 \ldots \\
\mathbf{R}-17 \ldots\end{array}$ & $\begin{array}{r}\text { Per cent. } \\
4.0 \\
9.0 \\
14.0 \\
19.0 \\
24.0\end{array}$ & \begin{tabular}{|r|} 
Per cent. \\
21.0 \\
16.0 \\
11.0 \\
6.0 \\
1.0
\end{tabular} & 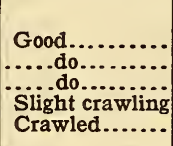 & \begin{tabular}{|} 
Good.... \\
$\ldots$. do...... \\
\hdashline$\ldots$ do..... \\
\hdashline$\ldots$ do..... \\
$\ldots$. do.....
\end{tabular} & 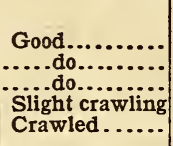 & 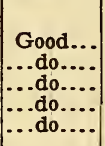 & $\begin{array}{l}\text { Good........... } \\
\text { B...do........... } \\
\text { Slight specks. } \\
\text { Crawled....... }\end{array}$ & $\begin{array}{l}\text { Good. } \\
\text { Do. } \\
\text { Do. } \\
\text { Do. } \\
\text { Do. }\end{array}$ \\
\hline
\end{tabular}

TABLE 4 F.-Effect of Varying Feldspar and Cryolite in White Cover Enamels.

[Constant portion melted, $12 \mathrm{SiO}_{2}, 9 \mathrm{~B}_{2} \mathrm{O}_{3}, 8.5 \mathrm{Na}_{2} \mathrm{O}, 16 \mathrm{PbO}, 6 \mathrm{ZnO}, 5.5 \mathrm{CaF}_{2}$ ]

\begin{tabular}{|c|c|c|c|c|c|c|c|c|}
\hline \multirow{3}{*}{$\begin{array}{l}\text { Enamel } \\
\text { No. }\end{array}$} & \multicolumn{2}{|c|}{$\begin{array}{l}\text { Melted weights } \\
\text { of variables. }\end{array}$} & \multicolumn{6}{|c|}{ Remarks. } \\
\hline & \multirow{2}{*}{ Feldspar. } & \multirow{2}{*}{ Cryolite. } & \multicolumn{2}{|c|}{$\mathbf{R g}-1$} & \multicolumn{2}{|c|}{$\mathrm{Rg}-7$} & \multicolumn{2}{|l|}{ Rg-16. } \\
\hline & & & Texture. & Opacity. & Texture. & Opacity. & Testure. & Opacity. \\
\hline $\begin{array}{l}R-1 \ldots . . . \\
R-13 a \ldots . . \\
R-18 \ldots . . \\
R-19 a . . . \\
R-19 . . .\end{array}$ & \begin{tabular}{|r|} 
Per cent. \\
38.0 \\
35.5 \\
33.0 \\
30.5 \\
28.0
\end{tabular} & $\begin{array}{r}\text { Per cent. } \\
5.0 \\
7.5 \\
10.0 \\
12.5 \\
15.0\end{array}$ & $\begin{array}{l}\text { Good.... } \\
\ldots . \text { do...... } \\
\ldots \ldots \text { do..... } \\
\ldots . \text { do..... } \\
\ldots . \text { do..... }\end{array}$ & $\begin{array}{l}\text { Good........ } \\
\text { Y..do...... } \\
\text { Very good... } \\
\ldots . . . \text { do.......... }\end{array}$ & \begin{tabular}{c} 
Good.... \\
$\ldots$. do..... \\
\hdashline$\ldots$ do..... \\
\hdashline. do..... \\
$\ldots$. do.....
\end{tabular} & 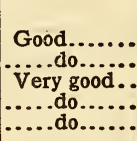 & 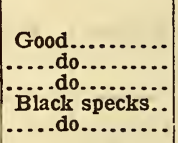 & $\begin{array}{l}\text { Good. } \\
\text { Do. } \\
\text { Do. } \\
\text { Do. } \\
\text { Do. }\end{array}$ \\
\hline
\end{tabular}

In Tables $4 \mathrm{~A}$ and $\mathrm{B}$ and Tables $5 \mathrm{~A}$ and $\mathrm{B}$ are shown the melted and batch weights of the compositions studied. These compositions can be grouped in series showing definite variations in composition, as shown in Tables $4 \mathrm{C}$ to $\mathrm{F}$ for enamels $\mathrm{R}-8$ to I9, based on $\mathrm{R}-\mathrm{I}$, and Tables $5 \mathrm{C}$ to $\mathrm{G}$ for enamels $\mathrm{R}-20$ to 35 , which are based on $\mathrm{R}-7$.

The compositions based on $\mathrm{R}-\mathrm{I}$ have flint, sodium oxide, zinc oxide, and fluorspar constant, since these were present in amounts usually required for satisfactory cover enamels. The flint was not replaced, as the refractoriness was varied in the different compositions by replacing the feldspar. Six per cent of zine oxide in a composition is about the usual amount contained in cast-iron cover enamels. An increase of this amount would induce crawling, while decreasing it would lessen the opacity of the enamel. An excessive amount of sodium oxide in the cover enamels produced pinholes. Sufficient sodium oxide was reserved in each composition to give about 5 per cent of sodium nitrate in the batch, which is necessary to prevent reduction of 
the lead compounds. The maximum amount of fluorspar usually added in cast-iron enamels is about 6 per cent.

For the reasons stated above the compounds of sodium oxide, zinc oxide, and fluorspar in the compositions based on $\mathrm{R}-7$ were not varied, and since lead oxide and boric oxide were the prinicpal fluxes it was not thought necessary to vary the amount of barium oxide.

\section{EFFECT OF VARYING FRIT COMPOSITIONS ON ENAMEL R-1.}

(a) Replacement of Feldspar by Boric Oxide.-As shown in Table $4 \mathrm{C}$, with boric oxide increased at the expense of feldspar, the results were not very favorable because of the decided tendency of the enamel to crawl or bead. An increase of 5 per cent of boric oxide over that for $\mathrm{R}-\mathrm{I}$, as in $\mathrm{R}-8$, gave results similar to $\mathrm{R}-\mathrm{I}$. Although the enamel did not show any tendency to crawl, the incipient pinholes were not entirely avoided. Further increases in boric oxide improved the texture of the enamel but increased the tendency to crawling when applied in a sufficiently heavy coat to give the desired opacity. In cover enamel, $\mathrm{R}-\mathrm{IO}$, the crawling was so increased that the enamel failed to cover the casting properly.

It will be noted that in lowering the refractoriness of the enamels by increasing the boric oxide the pinholes became fewer when these cover enamels were applied to the more fusible ground coats. The opacity was also improved, but some crawling occurred. From these results it was decided that I4 per cent of boric oxide was practically the limit in this particular type of composition in order to produce an enamel of the proper working qualities.

(b) Replacement of Feldspar by LEad Oxide.-The effect of increasing lead oxide at the expense of feldspar, as noted in Table $5 \mathrm{D}$, gave some very interesting and instructive results which show more definitely the relation between cover enamels and the different types of ground coats. The data indicated the most suitable cover compositions for each individual ground coat and appeared to support the assumption made in the preliminary study of this investigation. These compositions, on the whole, gave very good results. However, it was noted that certain samples were not satisfactory, owing to the appearance of black specks and the lack of opacity.

It was indicated that varying results could be expected with a particular cover coat, depending on the properties of the ground 
coat over which it had been applied. It will therefore be necessary in discussing the results obtained with the cover coats to consider the ground coats which had been used.

The best results obtained with $\mathrm{R}-\mathrm{I}$ I, containing $2 \mathrm{I}$ per cent of lead oxide, were in connection with $\mathrm{Rg}-\mathrm{I}$ ground coat. This combination appeared to give consistent results on a number of trials requiring apparently the same length of time to melt it down. The same composition with $\mathrm{Rg}-7$ and $\mathrm{I} 6$ showed a tendency to form pinholes and to develop black specks, probably due to the ground coat overfiring before the cover had matured. Cover enamel R-I2, containing 26 per cent of lead oxide, gave very good results with both $\mathrm{Rg}-\mathrm{I}$ and $\mathrm{I} 6$, but no improvement over the combination of cover enamel $\mathrm{R}-\mathrm{I}$ and ground coat $\mathrm{Rg}-\mathrm{I}$ could be observed.

Covers $\mathrm{R}-\mathrm{I}$ I or $\mathrm{I} 2$ in connection with the use of ground $\mathrm{Rg}-\mathrm{I}$ gave practically the same results with the exception of a slight decrease of opacity in $\mathrm{R}-\mathrm{I} 2$. With $3 \mathrm{I}$ per cent of lead oxide, as in $\mathrm{R}-\mathrm{I} 3$, pinholes were encountered, this cover giving best results with ground coat $\mathrm{Rg}-7$. With ground coat $\mathrm{Rg}-\mathrm{I}$ a few pinholes were observed.

The data given above show that the cover enamels should be fusible enough to flow down sufficiently, regardless of the composition of the ground coat. An excessive amount of lead oxide in the cover coats used on medium-hard ground coats results in pinholes. It is believed that the fusion point of ground coats and cover enamels should bear a close relation to each other, the best results being obtained when the ground is slightly the more refractory of the two.

(c) Replacement of Lead OXIDE by Boric Oxide.-The results obtained in replacing lead oxide by boric oxide (Table $4 \mathrm{E}$ ) were not as satisfactory as in the previous series. This variation maintained the refractoriness of the composition practically constant. The results showed clearly that neither of the two fluxes could be eliminated in the composition, as each gave certain necessary desirable properties in the enamel. In $\mathrm{R}-\mathrm{I} 4$, with 5 per cent of boric oxide replaced by lead oxide, little difference in opacity was noted over that of $\mathrm{R}-\mathrm{r}$. This enamel had a good texture, and consistent results were obtained with a number of samples. It was apparent that the effect of replacing boric oxide with lead oxide was more satisfactory than that of replacing feldspar by lead oxide, as the elasticity of the enamel was increased, permitting the application of a heavier coat. Crawling increased with the 
increase of boric oxide. Enamel R-15, in which 5 per cent of lead oxide was replaced by boric oxide, gave good results with ground coat $\mathrm{Rg}-\mathrm{I}$, as regards texture and opacity. The substitution of boric oxide for lead oxide slightly increased the refractoriness of the enamel and offered further evidence that the melting points of both compositions should be about the same, because R-I5, with both $\mathrm{Rg}-7$ and $\mathrm{Rg}-\mathrm{I} 6$, had a decided tendency to produce black specks. Very poor results were obtained with both R-I6 and $\mathrm{R}-\mathrm{I} 7$ in connection with the use of the three different ground coats. Crawling increased in proportion to the increase of boric oxide. In order to prevent crawling with these enamels, it would be necessary to apply them in such thin applications that the opacity would be lacking.

(d) Replacement of Feldspar by Cryolite.-As shown in Table $4 \mathrm{~F}$, where feldspar was replaced by cryolite, the results obtained were very satisfactory considering both texture and opacity. The advantage of replacing feldspar by cryolite rather than the replacement of feldspar by lead oxide was the increase of opacity as well as the fusibility of the composition. Replacing 5 per cent of the feldspar by cryolite gave very good results with the three different types of ground coats, but when Io per cent of feldspar was replaced by cryolite the results were not so favorable, pinholes being apparent in the cover enamels used with both $\mathrm{Rg}-\mathrm{I}$ and $\mathrm{Rg}-\mathrm{I}$. Aside from this feature it was noted that this enamel had a slight tendency to crawl when applied rather heavily. R-I $8 \mathrm{a}$, with 7.5 per cent of feldspar replaced by cryolite, gave results similar to those of $R-18$, while in $R-19 a$, with 12.5 per cent of feldspar replaced by cryolite, the same trouble was incurred as in R-I9, with a further increase of cryolite to I 5 per cent. The above results indicate that cryolite would not exceed Io per cent to give the most satisfactory results in cover enamels of this type.

\section{EFFECT OF VARYING FRIT COMPOSITIONS ON ENAMEL R-7.}

When using $\mathrm{R}-7$ as a basic composition the results obtained by the various substitutions were not as satisfactory in their entirety as those in the previous series because of the lack of opacity. However, several good compositions were developed, and the work showed definitely the different effects on cover enamels of this type when the same substitutions were made as in the previous series. As the basic composition $\mathrm{R}-7$ was con- 
siderably more fusible than $\mathrm{R}-\mathrm{I}$, the results with enamels in which the feldspar content remained constant or was increased proved more favorable than with enamels in which feldspar was decreased below the percentage of feldspar in the base enamel.

(a) RePlacement OF BORIC OXIDE BY Feldspar.-Enamel $\mathrm{R}-2 \mathrm{O}$ (Table $5 \mathrm{~A}$ ), in which the feldspar was increased 5 per cent at the expense of boric oxide, gave good results with ground coats $\mathrm{Rg}-\mathrm{I}$ and 7 , although the opacity was not exceptionally good in either case. Increasing the feldspar ro per cent at the expense of the boric oxide gave good results with the three different types of ground coats. The opacity was not improved over $\mathrm{R}-2 \mathrm{O}$, and in certain specimens there was a tendency to form black specks, the latter fact indicating that the cover enamel was too refractory for the different ground coats. Increasing the boric oxide 5 per cent at the expense of feldspar, as in cover $\mathrm{R}-22$, affected the properties of the composition as might be expected from the results obtained from $\mathrm{R}-2 \mathrm{O}$ and $2 \mathrm{I}$. This enamel, used with $\mathrm{Rg}-\mathrm{I}$ and $\mathrm{r} 6$, had poor texture and opacity. When used with $\mathrm{Rg}-7$ the enamel was free from black specks, but the opacity was not improved. Apparently the best combination obtained from this study was $\mathrm{R}-2 \mathrm{O}$ used in connection with ground coat $\mathrm{Rg}-\mathrm{I}$.

(b) Replacement of Lead Oxide by Feldspar.-In Table $5 \mathrm{D}$ is shown a series with lead oxide replaced by feldspar. The results obtained were fairly satisfactory as to texture, but opacity was lacking throughout the whole series. With these various substitutions $\mathrm{Rg}-\mathrm{I}$ appeared to be the most suitable ground coat. Increasing the lead oxide bettered the texture with enamels applied on ground coat $\mathrm{Rg}-\mathrm{I}$; however, a decrease of opacity was noticed as the lead oxide was increased.

Replacing 5 per cent of lead oxide with feldspar gave an enamel having good texture with either of the three types of grounds, but in each case opacity was lacking. Increasing feldspar ro per cent at the expense of lead oxide further decreased the opacity and caused the formation of pinholes when these cover enamels were used over the softer ground coats.

Replacing the feldspar by lead oxide gave rather poor results with $\mathrm{Rg}-7$ and 16 . Pinholes were formed and the opacity decreased proportionally with the increase of lead oxide. It was noted that the same composition used with $\mathrm{Rg}-\mathrm{I}$ gave enamels with fairly good texture. 
TABLE 5 A.-White-Cover Enamel of Series 5.

\begin{tabular}{|c|c|c|c|c|c|c|c|c|}
\hline \multirow{2}{*}{ Enamel number. } & \multicolumn{8}{|c|}{ Melted composition of frits. } \\
\hline & $\begin{array}{l}\text { Feld- } \\
\text { spar. }\end{array}$ & $\mathrm{B}_{2} \mathrm{O}_{3}$. & $\mathrm{Na}_{2} \mathrm{O}$ & $\mathrm{PbO}$. & ZnO. & $\mathrm{BaO}$. & $\mathrm{CaF}_{2}$. & $\begin{array}{l}\text { Cryo- } \\
\text { iite. }\end{array}$ \\
\hline 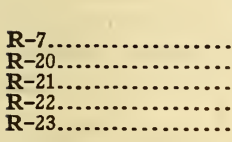 & \begin{tabular}{|r|} 
Per cent. \\
40.0 \\
45.0 \\
50.0 \\
35.0 \\
45.0
\end{tabular} & $\begin{array}{r}\text { Per cent. } \\
20.0 \\
15.0 \\
10.0 \\
25.0 \\
20.0\end{array}$ & $\begin{array}{r}\text { Per cent. } \\
11.0 \\
11.0 \\
11.0 \\
11.0 \\
11.0\end{array}$ & $\begin{array}{r}\text { Per cent. } \\
15.0 \\
15.0 \\
15.0 \\
15.0 \\
10.0\end{array}$ & $\begin{array}{r}\text { Per cent. } \\
5.0 \\
5.0 \\
5.0 \\
5.0 \\
5.0\end{array}$ & $\begin{array}{r}\text { Per cent. } \\
3.5 \\
3.5 \\
3.5 \\
3.5 \\
3.5\end{array}$ & \begin{tabular}{|r|} 
Per cent. \\
5.5 \\
5.5 \\
5.5 \\
5.5 \\
5.5
\end{tabular} & 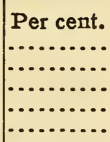 \\
\hline $\begin{array}{l}\mathbf{R}-24 \ldots \ldots \ldots \\
\mathbf{R}-25 \ldots \ldots \ldots \\
\mathbf{R}-26 \ldots \ldots \\
\mathbf{R}-27 \ldots \ldots\end{array}$ & $\begin{array}{l}50.0 \\
35.0 \\
30.0 \\
25.0\end{array}$ & $\begin{array}{l}20.0 \\
20.0 \\
20.0 \\
20.0\end{array}$ & $\begin{array}{l}11.0 \\
11.0 \\
11.0 \\
11.0\end{array}$ & $\begin{array}{r}5.0 \\
20.0 \\
25.0 \\
30.0\end{array}$ & $\begin{array}{l}5.0 \\
5.0 \\
5.0 \\
5.0\end{array}$ & $\begin{array}{l}3.5 \\
3.5 \\
3.5 \\
3.5\end{array}$ & $\begin{array}{r}-5.5 \\
5.5 \\
5.5 \\
5.5\end{array}$ & $\begin{array}{l}\ldots \ldots \\
\ldots \ldots \\
\ldots \ldots \\
\ldots \ldots \\
\ldots \ldots\end{array}$ \\
\hline $\begin{array}{l}\mathbf{R}-28 \ldots \ldots \ldots \\
\mathbf{R}-29 \ldots \ldots \\
\mathbf{R}-30 \ldots \ldots \\
\mathbf{R}-31 \ldots \ldots\end{array}$ & $\begin{array}{l}40.0 \\
40.0 \\
40.0 \\
40.0\end{array}$ & $\begin{array}{r}25.0 \\
15.0 \\
10.0 \\
5.0\end{array}$ & $\begin{array}{l}11.0 \\
11.0 \\
11.0 \\
11.0\end{array}$ & $\begin{array}{l}10 . J \\
20.0 \\
25.0 \\
30.0\end{array}$ & $\begin{array}{l}5.0 \\
5.0 \\
5.0 \\
5.0\end{array}$ & $\begin{array}{l}3.5 \\
3.5 \\
3.5 \\
3.5\end{array}$ & $\begin{array}{l}5.5 \\
5.5 \\
5.5 \\
5.5\end{array}$ & 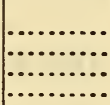 \\
\hline $\begin{array}{l}\mathbf{R}-32 \ldots \ldots \ldots \ldots \\
\mathbf{R}-33 \ldots \ldots \ldots \\
\mathbf{R}-34 \ldots \ldots \ldots \ldots \\
\mathbf{R}-35 \ldots \ldots \ldots\end{array}$ & $\begin{array}{l}35.0 \\
30.0 \\
40.0 \\
40.0\end{array}$ & $\begin{array}{l}20.0 \\
20.0 \\
15.0 \\
10.0\end{array}$ & $\begin{array}{l}11.0 \\
11.0 \\
11.0 \\
11.0\end{array}$ & $\begin{array}{r}15.0 \\
15.0 \\
15.0 \\
5.0\end{array}$ & $\begin{array}{l}5.0 \\
5.0 \\
5.0 \\
5.0\end{array}$ & $\begin{array}{l}3.5 \\
3.5 \\
3.5 \\
3.5\end{array}$ & $\begin{array}{l}5.5 \\
5.5 \\
5.5 \\
5.5\end{array}$ & $\begin{array}{r}5.0 \\
10.0 \\
5.0 \\
10.0\end{array}$ \\
\hline
\end{tabular}

TABLE 5 B.-White-Cover Enamels of Series 5.

\begin{tabular}{|c|c|c|c|c|c|c|c|c|c|c|}
\hline \multirow[b]{2}{*}{$\begin{array}{l}\text { Enamel } \\
\text { number. }\end{array}$} & \multicolumn{10}{|c|}{ Batch compositions for 100 parts of melted frit. } \\
\hline & $\begin{array}{l}\text { Feld- } \\
\text { spar. }\end{array}$ & Borax. & $\begin{array}{l}\text { Sodium } \\
\text { nitrate. }\end{array}$ & $\begin{array}{l}\text { Soda } \\
\text { ash. }\end{array}$ & $\begin{array}{l}\text { Red } \\
\text { lead. }\end{array}$ & $\begin{array}{c}\text { Zinc } \\
\text { oxide. }\end{array}$ & $\begin{array}{l}\text { Barium } \\
\text { carbon- } \\
\text { ate. }\end{array}$ & $\begin{array}{l}\text { Fluor- } \\
\text { spar. }\end{array}$ & $\begin{array}{l}\text { Cryo- } \\
\text { lite. }\end{array}$ & $\begin{array}{l}\text { Boric } \\
\text { acid. }\end{array}$ \\
\hline $\begin{array}{l}\mathbf{R}-7 \ldots \ldots \ldots \\
\mathbf{R}-20 \ldots \ldots \ldots \\
\mathbf{R}-21 \ldots \ldots \ldots \\
\mathbf{R}-22 \ldots \ldots \ldots \\
\mathbf{R}-23 \ldots \ldots \ldots\end{array}$ & $\begin{array}{l}40.0 \\
45.0 \\
50.0 \\
35.0 \\
45.0\end{array}$ & $\begin{array}{l}24.52 \\
41.0 \\
27.3 \\
54.5 \\
54.5\end{array}$ & $\begin{array}{l}5.95 \\
5.95 \\
5.95 \\
5.95 \\
5.95\end{array}$ & $\begin{array}{r}\ldots \ldots . . \\
3.73 \\
7.55 \\
\ldots \ldots \ldots \\
\cdots \ldots \ldots\end{array}$ & $\begin{array}{l}15.4 \\
15.4 \\
15.4 \\
15.4 \\
10.3\end{array}$ & $\begin{array}{l}5.0 \\
5.0 \\
5.0 \\
5.0 \\
5.0\end{array}$ & $\begin{array}{l}4.5 \\
4.5 \\
4.5 \\
4.5 \\
4.5\end{array}$ & $\begin{array}{l}5.5 \\
5.5 \\
5.5 \\
5.5 \\
5.5\end{array}$ & 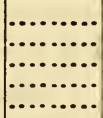 & 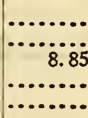 \\
\hline $\begin{array}{l}\mathbf{R}-24 \ldots \ldots \ldots \\
\mathbf{R}-25 \ldots \ldots \ldots \\
\mathbf{R}-26 \ldots \ldots \ldots \\
\mathbf{R}-27 \ldots \ldots \ldots\end{array}$ & $\begin{array}{l}50.0 \\
35.0 \\
30.0 \\
25.0\end{array}$ & $\begin{array}{l}54.5 \\
54.5 \\
54.5 \\
54.5\end{array}$ & $\begin{array}{l}5.95 \\
5.95 \\
5.95 \\
5.95\end{array}$ & 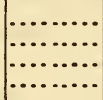 & $\begin{array}{l}5.15 \\
20.6 \\
25.7 \\
30.9\end{array}$ & $\begin{array}{l}5.0 \\
5.0 \\
5.0 \\
5.0\end{array}$ & $\begin{array}{l}4.5 \\
4.5 \\
4.5 \\
4.5\end{array}$ & $\begin{array}{l}5.5 \\
5.5 \\
5.5 \\
5.5\end{array}$ & & $\begin{array}{l}\ldots \ldots \ldots \\
\ldots \ldots \ldots \\
\ldots \ldots \ldots \\
\ldots \ldots \ldots\end{array}$ \\
\hline $\begin{array}{l}\mathbf{R}-28 \ldots \ldots \ldots \\
\mathbf{R}-29 \ldots \ldots \ldots \\
\mathbf{R}-30 \ldots \ldots \ldots \\
\mathbf{R}-31 \ldots \ldots \ldots\end{array}$ & $\begin{array}{l}40.0 \\
40.0 \\
40.0 \\
40.0\end{array}$ & $\begin{array}{l}54.5 \\
41.0 \\
27.3 \\
13.6\end{array}$ & $\begin{array}{l}5.95 \\
5.95 \\
5.95 \\
5.95\end{array}$ & $\begin{array}{r}3.73 \\
7.55 \\
11.30\end{array}$ & $\begin{array}{l}10.3 \\
20.6 \\
25.7 \\
30.9\end{array}$ & $\begin{array}{l}5.0 \\
5.0 \\
5.0 \\
5.0\end{array}$ & $\begin{array}{l}4.5 \\
4.5 \\
4.5 \\
4.5\end{array}$ & $\begin{array}{l}5.5 \\
5.5 \\
5.5 \\
5.5\end{array}$ & & 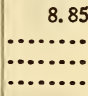 \\
\hline $\begin{array}{l}\mathbf{R}-32 \ldots \ldots \ldots \\
\mathbf{R}-33 \ldots \ldots \ldots \\
\mathbf{R}-34 \ldots \ldots \ldots \\
\mathbf{R}-35 \ldots \ldots \ldots\end{array}$ & $\begin{array}{l}35.0 \\
30.0 \\
40.0 \\
40.0\end{array}$ & $\begin{array}{l}54.5 \\
54.5 \\
41.0 \\
27.3\end{array}$ & $\begin{array}{l}5.95 \\
5.95 \\
5.95 \\
5.95\end{array}$ & $\begin{array}{r}\ldots .73 \\
3.73 \\
7.55\end{array}$ & $\begin{array}{l}15.4 \\
15.4 \\
15.4 \\
15.4\end{array}$ & $\begin{array}{l}5.0 \\
5.0 \\
5.0 \\
5.0\end{array}$ & $\begin{array}{l}4.5 \\
4.5 \\
4.5 \\
4.5\end{array}$ & $\begin{array}{l}5.5 \\
5.5 \\
5.5 \\
5.5\end{array}$ & $\begin{array}{r}5.0 \\
10.0 \\
5.0 \\
10.0\end{array}$ & $\begin{array}{l}\ldots \ldots \ldots \\
\ldots \ldots \ldots \ldots \\
\ldots \ldots \ldots\end{array}$ \\
\hline
\end{tabular}

TABLE 5 C.-Effect of Varying Feldspar and Boric Oxide in White-Cover Enamels, Based on R-7.

[Constant portion melted, $11 \mathrm{Na}_{2} \mathrm{O}, 15 \mathrm{PbO}, 5 \mathrm{ZnO}, 3.5 \mathrm{BaO}, 5.5 \mathrm{CaF}_{2 .}$ ]

\begin{tabular}{|c|c|c|c|c|c|c|c|c|}
\hline \multirow{3}{*}{$\begin{array}{l}\text { Enamel } \\
\text { number. }\end{array}$} & \multicolumn{2}{|c|}{$\begin{array}{l}\text { Melted weights of } \\
\text { variables. }\end{array}$} & \multicolumn{6}{|c|}{ Remarks. } \\
\hline & \multirow{2}{*}{ Feldspar. } & \multirow{2}{*}{$\dot{\mathrm{B}_{2}} \mathrm{O}_{3}$} & \multicolumn{2}{|c|}{$\mathbf{R g}-1}$. & \multicolumn{2}{|c|}{$\mathrm{Rg}-7$} & \multicolumn{2}{|l|}{$\mathbf{R g}-16$} \\
\hline & & & Texture. & Opacity. & Texture. & Opacity. & Testure. & Opacity. \\
\hline $\begin{array}{l}\mathbf{R}-21 \ldots . . \\
\mathbf{R}-20 \ldots . \\
\mathbf{R}-7 . \ldots . \\
\mathbf{R}-22 \ldots .\end{array}$ & \begin{tabular}{|r|} 
Per cent. \\
50.0 \\
45.0 \\
40.0 \\
35.0
\end{tabular} & \begin{tabular}{|r|} 
Per cent. \\
10.0 \\
15.0 \\
20.0 \\
25.0
\end{tabular} & \begin{tabular}{c} 
Good............ \\
$\ldots \ldots$. do.......... \\
\hdashline Black specks...
\end{tabular} & $\begin{array}{c}\text { Fair...... } \\
\ldots . \text { do...... } \\
\text { ‥do..... } \\
\text { Poor... }\end{array}$ & $\begin{array}{c}\text { Good..... } \\
\ldots . \text { do...... } \\
\ldots . \text { do..... } \\
\ldots . \text { do..... }\end{array}$ & \begin{tabular}{l} 
Fair....... \\
$\ldots$. do...... \\
\hdashline. do...... \\
$\ldots$. do.....
\end{tabular} & \begin{tabular}{c} 
Good............ \\
\hdashline$\ldots .$. do............. \\
\hdashline Black specks...
\end{tabular} & $\begin{array}{l}\text { Fair. } \\
\text { Do. } \\
\text { Good. } \\
\text { Poor. }\end{array}$ \\
\hline
\end{tabular}


TABLE 5 D. - Effect of Varying Feldspar and Lead Oxide in White-Cover Enamels.

[Constant portion melted, $20 \mathrm{~B}_{2} \mathrm{O}_{3}, 11 \mathrm{Na}_{2} \mathrm{O}, 5 \mathrm{ZnO}, 3.5 \mathrm{BaO}, 5.5 \mathrm{CaF}_{2}$.]

\begin{tabular}{|c|c|c|c|c|c|c|c|c|}
\hline \multirow{3}{*}{ Enamel number. } & \multicolumn{2}{|c|}{$\begin{array}{l}\text { Melted weights of } \\
\text { variables. }\end{array}$} & \multicolumn{6}{|c|}{ Remarks. } \\
\hline & \multirow{2}{*}{ Feldspar. } & \multirow{2}{*}{$\mathrm{PbO}$. } & \multicolumn{2}{|c|}{$\mathrm{Rg}-1$} & \multicolumn{2}{|c|}{$\mathrm{Rg}-7}$. & \multicolumn{2}{|c|}{ Rg-16. } \\
\hline & & & Texture. & Opacity. & Texture. & Opacity. & Texture. & Opacity. \\
\hline 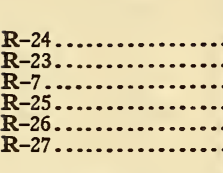 & $\begin{array}{r}\text { Per cent. } \\
50.0 \\
45.0 \\
40.0 \\
35.0 \\
30.0 \\
25.0\end{array}$ & $\begin{array}{r}\text { Per cent. } \\
5.0 \\
10.0 \\
15.0 \\
20.0 \\
25.0 \\
30.0\end{array}$ & $\begin{array}{l}\text { Good.... } \\
\ldots . \text { do..... } \\
\ldots . \text { do..... } \\
\ldots \text {.do..... } \\
\ldots \text {.do..... } \\
\ldots . \text { do..... }\end{array}$ & \begin{tabular}{c} 
Fair...... \\
$\ldots$. do...... \\
\hdashline. do..... \\
Poor..... \\
$\ldots$. do $\ldots . . .$. \\
$\ldots$. do.....
\end{tabular} & \begin{tabular}{|l} 
Good..... \\
$\ldots$. do $\ldots . .$. \\
$\ldots$. do..... \\
$\ldots$. do...... \\
$\ldots$. do..... \\
$\ldots$. do.....
\end{tabular} & 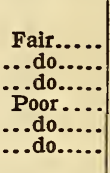 & 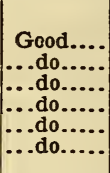 & $\begin{array}{l}\text { Fair. } \\
\text { Do. } \\
\text { Do. } \\
\text { Poor. } \\
\text { Do. } \\
\text { Do. }\end{array}$ \\
\hline
\end{tabular}

TABLE 5 E.-Effect of Varying Boric Oxide and Lead Oxide in White-Cover Enamels.

[Constant portion melted, 40 feldspar, $11 \mathrm{Na}_{2} \mathrm{O}, 5 \mathrm{ZnO}, 3.5 \mathrm{BaO}, 5.5 \mathrm{CaF}_{2 .}$ ]

\begin{tabular}{|c|c|c|c|c|c|c|c|c|}
\hline \multirow{3}{*}{$\underset{\substack{\text { Enamel } \\
\text { ber. }}}{\text {. }}$} & \multicolumn{2}{|c|}{$\begin{array}{l}\text { Melted weights } \\
\text { of variables. }\end{array}$} & \multicolumn{6}{|c|}{ Remarks. } \\
\hline & \multirow{2}{*}{$\mathrm{B}_{2} \mathrm{O}_{3}$} & \multirow{2}{*}{ PbO. } & \multicolumn{2}{|l|}{ Rg-1. } & \multicolumn{2}{|l|}{$\mathbf{R g}-7$} & \multicolumn{2}{|l|}{ Rg-16. } \\
\hline & & & Texture. & Opacity. & Texture. & Opacity. & Texture. & Opacity. \\
\hline $\begin{array}{l}\mathbf{R}-28 \ldots \\
\mathbf{R}-7 \ldots . \\
\mathrm{R}-29 \ldots \\
\mathbf{R}-30 \ldots \\
\mathbf{R}-31 \ldots\end{array}$ & $\begin{array}{r}\text { Per ct. } \\
25.0 \\
20.0 \\
15.0 \\
10.0 \\
5.0\end{array}$ & $\begin{array}{r}\text { Per ct. } \\
10.0 \\
15.0 \\
20.0 \\
25.0 \\
30.0\end{array}$ & 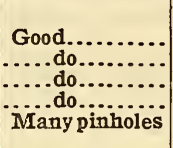 & \begin{tabular}{c} 
Good.... \\
Fair..... \\
$\ldots$. do..... \\
\hdashline.. do..... \\
$\ldots$. do....
\end{tabular} & 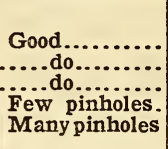 & $\begin{array}{c}\text { Good... } \\
\text { Fair.... } \\
\ldots . \text { do.... } \\
\ldots . \text { do } \ldots . . . \\
\ldots . \text { do } \ldots . . .\end{array}$ & $\begin{array}{l}\text { Good............ } \\
\text { Black specks... } \\
\text { Few pinholes. } \\
\text { Many pinholes }\end{array}$ & $\begin{array}{l}\text { Good. } \\
\text { Do. } \\
\text { Do. } \\
\text { Fair. } \\
\text { Do. }\end{array}$ \\
\hline
\end{tabular}

TABLE 5 F.-Effect of Varying Feldspar and Cryolite in White-Cover Enamels.

[Constant portion melted, $20 \mathrm{~B}_{2} \mathrm{O}_{3}, 11 \mathrm{Na}_{2} \mathrm{O}, 15 \mathrm{PbO}, 5 \mathrm{ZnO}, 3.5 \mathrm{BaO}, 5.5 \mathrm{CaF}_{2 .}$ ]

\begin{tabular}{|c|c|c|c|c|c|c|c|c|}
\hline \multirow{3}{*}{$\begin{array}{c}\text { Enamel } \\
\text { num- } \\
\text { ber. }\end{array}$} & \multicolumn{2}{|c|}{$\begin{array}{l}\text { Melted weights } \\
\text { of variables. }\end{array}$} & \multicolumn{6}{|c|}{ Remarks. } \\
\hline & \multirow{2}{*}{$\begin{array}{l}\text { Feld- } \\
\text { spar. }\end{array}$} & \multirow{2}{*}{$\begin{array}{l}\text { Cryo- } \\
\text { lite. }\end{array}$} & \multicolumn{2}{|l|}{ Rg-1. } & \multicolumn{2}{|l|}{ Rg-7. } & \multicolumn{2}{|l|}{ Rg-16. } \\
\hline & & & Texture. & Opacity. & Texture. & Opacity. & Texture. & Opacity. \\
\hline $\begin{array}{l}R-7 \ldots \\
R-32 \ldots \\
R-33 \ldots\end{array}$ & $\begin{array}{r}\text { Per ct. } \\
40.0 \\
35.0 \\
30.0\end{array}$ & $\begin{array}{r}\text { Per ct. } \\
5.0 \\
10.0\end{array}$ & $\begin{array}{l}\text { Good........... } \\
\text { Fine pinholes. } \\
\text { Crawled; few } \\
\text { pinholes. }\end{array}$ & $\begin{array}{c}\text { Fair..... } \\
\text { Poor..... }\end{array}$ & $\begin{array}{l}\text { Good.......... } \\
\text { Black specks.. } \\
\text { C r a w 1 ed ; } \\
\text { many pin- } \\
\text { holes. }\end{array}$ & $\begin{array}{l}\text { Fair.... } \\
\text { Poor... } \\
\text {...do.... }\end{array}$ & \begin{tabular}{c} 
Good............. \\
\hdashline cra w w le d ; \\
black specks.
\end{tabular} & $\begin{array}{l}\text { Good. } \\
\text { Poor. } \\
\text { Do. }\end{array}$ \\
\hline
\end{tabular}

TABLE 5 G.-Effect of Varying Boric Oxide and Cryolite in White-Cover Enamels.

[Constant portion melted, 40 feldspar, $11 \mathrm{Na} 2 \mathrm{O}, 15 \mathrm{PbO}, 5 \mathrm{ZnO}, 3.5 \mathrm{BaO}, 5.5 \mathrm{CaF}_{2 .}$ ]

\begin{tabular}{|c|c|c|c|c|c|c|c|c|}
\hline \multirow{3}{*}{$\begin{array}{c}\text { Enamel } \\
\text { num- } \\
\text { ber. }\end{array}$} & \multicolumn{2}{|c|}{$\begin{array}{l}\text { Melted weights } \\
\text { of variables. }\end{array}$} & \multicolumn{6}{|c|}{ Remarks. } \\
\hline & \multirow{2}{*}{$\mathrm{B}_{2} \mathrm{O}_{3}$. } & \multirow{2}{*}{$\begin{array}{l}\text { Cryo- } \\
\text { lite. }\end{array}$} & \multicolumn{2}{|l|}{$\mathbf{R g}-1$} & \multicolumn{2}{|l|}{$\mathbf{R g}-7$} & \multicolumn{2}{|l|}{ Rg-16. } \\
\hline & & & Texture. & Opacity. & Texture. & Opacity. & Texture. & Opacity. \\
\hline $\begin{array}{l}\text { R-7.... } \\
\text { R-34... } \\
\text { R-35... }\end{array}$ & $\begin{array}{r}\text { Per ct. } \\
20.0 \\
15.0 \\
10.0\end{array}$ & $\begin{array}{r}\text { Per ct. } \\
5.0 \\
10.0\end{array}$ & 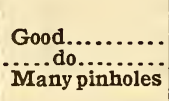 & $\begin{array}{l}\text { Fair...... } \\
\text { Poor...... }\end{array}$ & $\begin{array}{l}\text { Good........... } \\
\text { Crawled...... } \\
\text { Few pinholes. }\end{array}$ & $\begin{array}{c}\text { Fair.... } \\
\text { Podo.... } \\
\text { Poor... }\end{array}$ & $\begin{array}{l}\text { Good.......... } \\
\text { Few pinholes.. } \\
\ldots . . . \text { do........... }\end{array}$ & $\begin{array}{l}\text { Good. } \\
\text { Fair. } \\
\text { Foor }\end{array}$ \\
\hline
\end{tabular}


From the data given above it was decided that a high content of lead oxide decreased the opacity of the enamel. Cover R-23, when used with ground $\mathrm{Rg}-\mathrm{I}$, apparently gave the best results of any enamel in this series.

(c) REPLACEMENT OF BORIC OXIDE BY LEAD OXIDE.-Replacing lead oxide by boric oxide (Table $5 \mathrm{E}$ ) produced enamels having more desirable properties than those obtained in the previous series based on enamel $\mathrm{R}-7$. The most satisfactory composition developed in this series was $\mathrm{R}-28$. The properties of this enamel were such that good results were obtained with the three different types of ground coats.

Cover enamel $\mathrm{R}-28$ contained 25 per cent of boric oxide. This amount is unusually high, but for this particular type of enamel a high boric-oxide content gave the best results as regards opacity. However, it was noted that more care was required in the manipulation, as a composition of this kind is more liable to crawl than the lead type. Increasing the lead oxide at the expense of boric oxide, as in compositions $\mathrm{R}-29,3 \mathrm{O}$, and $3 \mathrm{I}$, produced enamels with lower viscosity. However, many of the trials developed pinholes and black specks, and these defects were noticeable when any of the three types of ground coats was used. The opacity was decidedly decreased with the increase of lead oxide, and with increase of I 5 per cent the enamel approached the transparency of a clear glass.

(d) Replacement of Feldspar by CRYolite.-The replacement of feldspar by cryolite (Table $5 \mathrm{~F}$ ) in this type of enamel did not prove very successful. The most serious objection was crawling, while the texture and opacity were not improved to any noticeable extent.

The fact that cryolite had vastly different effects in the two types of basic enamels shows rather definitely that a general statement can not be made as to its effect in different types of compositions.

The lack of opacity in the enamels containing the greater proportions of cryolite may be due to the increased fusibility of the enamels, probably allowing easy volatilization of the fluorine and solution of the opacifying agents.

It was also noted that in increasing cryolite at the expense of feldspar and boric oxide, crawling of the enamel occurred.

(e) Replaceinent of Boric OXIDE By CRYolite.-The replacement of boric oxide by cryolite (Table $5 \mathrm{G}$ ), as in $\mathrm{R}-34$ and 35 , gave results which were very similar to those obtained with $\mathrm{R}-32$ 
and 33. The enamels had a decided tendency to crawl, and the texture was not satisfactory when either composition was used with any of the three different types of ground coats.

It will be noted that quite different results were obtained by varying the same constituents in the composition of $R-I$ and 7 . The most appreciable difference was noted when the effect of cryolite in these compositions was studied. The same amount of boric oxide in the two compositions gave decidedly different results. It is evident that the limit for boric oxide is higher in the case of the more fusible enamels. This may be due to the fact that the refractory enamels are comparatively viscous, and this property is emphasized by the additions of such a substance as boric oxide.

The different effects in the two compositions show rather definitely that the effects of boric oxide and cryolite can be stated only in relation to a definite composition.

\section{GENERAL CONCLUSIONS FROM STUDY OF ENAMELS WITH GROUND COATS.}

It is apparent from this investigation that all ground-coat compositions are not necessarily suitable for both the dry and wet process, although certain compositions seem to be satisfactory when used for either type of cover enamel.

The preparation of ground coats for the wet process seems to require considerably more care than is necessary in dry-process enameling of cast iron. Sintering of the ground-coat frit is recommended, since melting of the materials to a glass lowers the power of adherence of the ground coat to the iron. This was true of all compositions studied, regardless of their fusibility when applied to the casting; that is, whether they melted to a glassy coating or retained the dull matt appearance of true sintered ground coats.

Excessive additions of raw materials to the mill batch for ground coats is to be discouraged. Clay and flint as mill additions give the best results, although the limits for these are fairly low. Large additions of clay and flint caused flaking of the enamel from the iron, while feldspar caused the formation of pinholes. Fifteen per cent of clay or Io per cent each of clay and fint are recommended as mill additions for the ground coats.

The use of a combination of lead, boric, and sodium oxides is desirable, since the introduction of an excessively large amount of any one flux gives rise to various difficulties. 
Sodium oxide in excess of about ro per cent in the melted batch causes blistering of the enamels. The limit for boric oxide is in the neighborhood of 19 per cent. Additions above this amount tend to cause crawling of the enamel if the latter is applied in too thick a coat. Boric oxide, however, has the property of increasing the firing range of the enamel, and for that reason as large an amount as possible, without causing crawling, should be used. Lead oxide improves the adherence of the enamel, and the use of as much as 20 to 25 per cent in the melted batch does not appear to be detrimental.

The cover enamels may be melted to a glass by the usual smelting process. Suitable mill additions consist of 5 per cent clay, 8 per cent tin oxide, and 45 per cent water, all based on the weight of the dry frit.

For the best results the cover enamel must be adapted to the ground coat in refractoriness. If the cover enamel is too refractory, blistering will result. Boric oxide increased the firing range of the enamels but tended to promote crawling, although this was less pronounced in the more fusible compositions. When substituted for sodium and lead oxides, however, boric oxide increased the opacity of the enamels. Cryolite also increased the opacity, but additions of about Io per cent tended to promote crawling.

While consideration must be given to the comparative refractoriness of the ground and cover coats and to the methods of preparation of the enamels as discussed in this paper, the following compositions may be mentioned as typical of those giving satisfactory results:

Ground-Coat Frits.

\begin{tabular}{|c|c|c|c|c|c|}
\hline \multirow{2}{*}{ Materials. } & \multicolumn{5}{|c|}{ Batch compositions to give 100 parts of melted frit. } \\
\hline & $\mathrm{Rg}-26$ & Rg-17. & Rg-1. & $\mathrm{Rg}-25$ & $\mathrm{Rg}-18$ \\
\hline 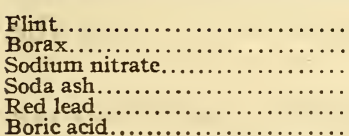 & $\begin{array}{r}66.30 \\
36.96 \\
6.95\end{array}$ & \begin{tabular}{r}
69.90 \\
36.96 \\
6.95 \\
\hdashline 4.08 \\
7.08
\end{tabular} & $\begin{array}{r}69.90 \\
36.96 \\
6.95 \\
\hdashline \% .17\end{array}$ & $\begin{array}{r}69.90 \\
26.07 \\
6.95 \\
9.88 \\
8.17\end{array}$ & $\begin{array}{r}69.90 \\
26.07 \\
6.95 \\
3.04 \\
12.24\end{array}$ \\
\hline
\end{tabular}

Mill Batch for Ground Coats.

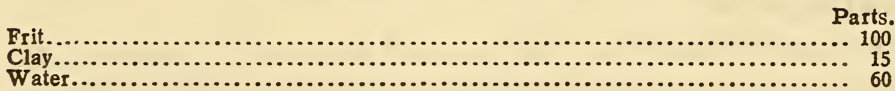


White-Cover Enamel Frits.

\begin{tabular}{|c|c|c|c|c|c|}
\hline \multirow{2}{*}{ Miaterials. } & \multicolumn{5}{|c|}{ Batch compositions for 100 parts of melted frit. } \\
\hline & $\mathbf{R}-14$ & $\mathrm{R}-11$ & $\mathbf{R}-28$ & $\mathbf{R}-1$ & $\mathbf{R}-18$ \\
\hline 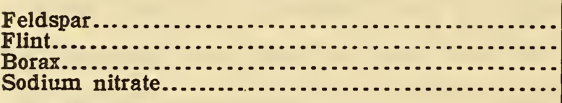 & $\begin{array}{r}38.0 \\
12.0 \\
10.9 \\
6.2\end{array}$ & $\begin{array}{l}33.0 \\
12.0 \\
24.52 \\
6.20\end{array}$ & $\begin{array}{c}40.0 \\
54.5 \\
5.95\end{array}$ & $\begin{array}{l}38.0 \\
12.0 \\
24.52 \\
6.20\end{array}$ & $\begin{array}{l}33.0 \\
12.0 \\
24.52 \\
6.20\end{array}$ \\
\hline 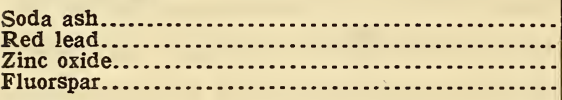 & $\begin{array}{r}7.7 \\
21.6 \\
6.0 \\
5.5\end{array}$ & $\begin{array}{r}3.86 \\
21.60 \\
6.0 \\
5.5\end{array}$ & $\begin{array}{r}10.3 \\
5.0 \\
5.5\end{array}$ & $\begin{array}{c}3.86 \\
16.42 \\
6.0 \\
5.5\end{array}$ & $\begin{array}{r}3.86 \\
16.42 \\
6.00 \\
5.50\end{array}$ \\
\hline 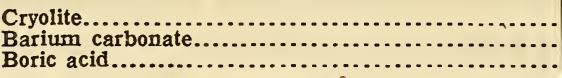 & $\begin{array}{r}5.0 \\
\ldots .\end{array}$ & $\begin{array}{c}5.0 \\
\ldots . . . \cdots\end{array}$ & $\begin{array}{l}4.5 \\
8.85\end{array}$ & $\begin{array}{c}5.0 \\
\ldots \ldots .\end{array}$ & $\begin{aligned} 10.00 \\
\cdots\end{aligned}$ \\
\hline
\end{tabular}

Mill Batches for White Cover Enamels.

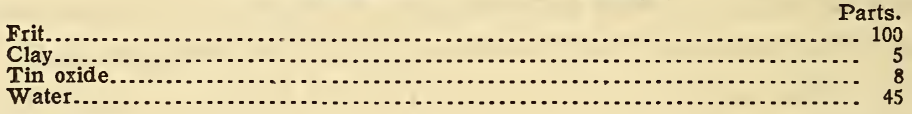

\section{PART II.-WET-PROCESS ENAMELS WITHOUT THE USE OF A GROUND COAT.}

\section{INTRODUCTION.}

Wet-process enamels, to be applied directly to the iron without the use of a ground coat, have become very popular in the stove industry because of the fact that one entire operation is eliminated. In order to complete this investigation, a study has been made of both colored and white enamels of this type.

In the production of such enamels two properties are of importance, namely, the adherence that the ordinary ground coat possesses and the texture of a desirable cover enamel. Therefore a ground coat which had developed considerable gloss was selected as a basic composition for this study.

\section{PREPARATION OF ENAMELS.}

The enamels were prepared by weighing in 5-pound batches, mixing thoroughly, and then smelting in crucibles. The temperature of smelting for the individual enamels varied with the fusibility of the compositions. The time required to melt the batches varied from 30 to 45 minutes.

When smelting opaque enamels, no attempt was made to drive off the gas completely, but the enamels were poured when all of the raw material was completely melted. The enamels were quenched in water.

The mill additions for the colored enamels consisted of 4 per cent clay and I per cent of a commercial blue green coloring oxide, with the necessary amount of water to form a slip for spraying. The same clay content was used for the white enamels, except that the color oxide was replaced by 4 per cent of tin oxide. 
The cast-iron specimens for tests were oval-shaped disks used in the manufacture of enameled stoves and were similar to those used in the previous study. The castings were prepared for enameling as usual by annealing and then sand-blasting with a-mixture of about 80 per cent sand and 20 per cent crushed-steel shot.

The clean castings were coated with the various enamels by means of an air spray. These were dried thoroughly and then fired in an electric furnace at a temperature varying from 730 to $790^{\circ} \mathrm{C}$. ( $\mathrm{I}, 350$ to $\mathrm{I}, 45^{\circ} \mathrm{F}$.). The time of firing varied from three to six minutes. It may be well to emphasize the fact that a thin and even coat of enamel should be applied to the casting if crawling is to be avoided. Following the firing and cooling of the first coat a second coat, if desired, may be applied.

\section{STUDY OF SINGLE-COAT COLORED ENAMELS.}

\section{BASIC COMPOSITIONS FOR STUDY.}

In Tables $6 \mathrm{~A}$ and $\mathrm{B}$ are shown the melted and the batch weights of 13 enamel compositions based on $\mathrm{Rg}-7$, a composition of the flint type, and 9 enamel compositions (Tables $7 \mathrm{~A}$ and B), based on $\mathrm{Rg}-4 \mathrm{a}$, a composition of the feldspar type. These compositions had shown excellent gloss and burning properties, and it was expected they would make a good color base.

As in the previous study on wet-process enamels used with ground coats, the various compositions were divided into series. The Tables $6 \mathrm{C}$ to $\mathrm{G}$ show these variations and the effect produced by them.

\section{EFFECT OF VARYING THE COMPOSITION OF ENAMEL RG-7.}

(a) REPLACEMENT OF FlinT BY CRYolite.-Table $6 \mathrm{C}$ shows the effect of replacing flint by cryolite. Ground coat $\mathrm{Rg}-7$, which had been used in the previous study on the two or three coat process in connection with the use of a ground coat, was chosen as a basic composition. Increasing the cryolite content at the expense of flint did not produce satisfactory enamels. The compositions $\mathrm{Rh}-8$ and 9 did not possess the desired gloss. Enamels $\mathrm{Rh}$-Io and II, containing a higher content of cryolite, were more satisfactory in this respect but showed a decided tendency to crawl. It was noted, however, in this series that adherence was greatly improved with the replacement of flint by cryolite.

(b) REPLACEMENT OF FLINT BY LEAd OXIDE.-In Table $6 \mathrm{D}$ is shown the effect of replacing flint by lead oxide. From the results obtained it was quite evident that a higher content of lead oxide was beneficial in developing gloss of the enamels. These compositions possessed a good gloss, and the crawling that 
prevailed in the cryolite series was eliminated when the enamel was applied in coats of proper thickness. An increase of 5 per cent of lead oxide at the expense of flint, as in Rh-I2, did not improve the enamel, as the latter showed a tendency to develop pinholes and to chip. The adherence was improved when ro per cent of flint was replaced by lead oxide.

TABLE 6 A.-Melted Compositions of Frits for Colored Enamels Based on Composition Rg-7.

\begin{tabular}{|c|c|c|c|c|c|}
\hline \multirow{2}{*}{ Enamel number. } & \multicolumn{5}{|c|}{ Melted composition of frits. } \\
\hline & Flint. & $\mathrm{B}_{2} \mathrm{O}_{3}$ & $\mathrm{Na}_{2} \mathrm{O}$ & PbO. & Cryolite. \\
\hline 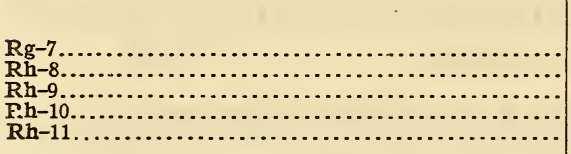 & \begin{tabular}{|r|} 
Per cent. \\
62.7 \\
57.7 \\
52.7 \\
47.7 \\
42.7
\end{tabular} & \begin{tabular}{r|} 
Per cent. \\
13.57 \\
13.57 \\
13.57 \\
13.57 \\
13.57
\end{tabular} & \begin{tabular}{|r|} 
Per cent. \\
8.53 \\
8.53 \\
8.53 \\
8.53 \\
8.53
\end{tabular} & \begin{tabular}{r|} 
Per cent. \\
15.20 \\
15.20 \\
15.20 \\
15.20 \\
15.20
\end{tabular} & $\begin{array}{r}\text { Per cent. } \\
5.00 \\
10.00 \\
15.00 \\
20.00\end{array}$ \\
\hline 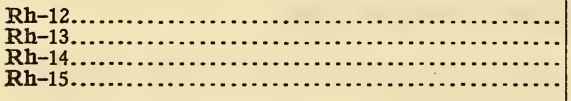 & $\begin{array}{l}57.7 \\
52.7 \\
47.7 \\
60.2\end{array}$ & \begin{tabular}{l|}
13.57 \\
12.57 \\
13.57 \\
16.07
\end{tabular} & $\begin{array}{l}8.53 \\
8.53 \\
8.53 \\
8.53\end{array}$ & $\begin{array}{l}20.20 \\
25.20 \\
30.20 \\
15.20\end{array}$ & 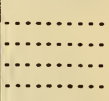 \\
\hline 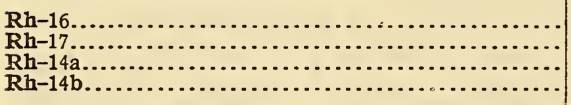 & $\begin{array}{l}57.7 \\
55.2 \\
42.7 \\
37.7\end{array}$ & $\begin{array}{l}18.57 \\
21.07 \\
13.57 \\
13.57\end{array}$ & $\begin{array}{l}8.53 \\
8.53 \\
8.53 \\
8.53\end{array}$ & $\begin{array}{l}15.20 \\
15.20 \\
35.20 \\
40.20\end{array}$ & … \\
\hline
\end{tabular}

TABLE 6 B.-Batch Compositions of Frits for Colored Enamels Based on Composition $\mathrm{Rg}-7$.

\begin{tabular}{|c|c|c|c|c|c|c|}
\hline \multirow[b]{2}{*}{ Enamel number. } & \multicolumn{6}{|c|}{ Batch compositions for 100 parts of melted frit. } \\
\hline & Flint. & Borax. & $\begin{array}{l}\text { Sodium } \\
\text { nitrate. }\end{array}$ & $\begin{array}{l}\text { Red } \\
\text { lead. }\end{array}$ & $\begin{array}{l}\text { Cryo- } \\
\text { lite. }\end{array}$ & $\begin{array}{l}\text { Boric } \\
\text { acid. }\end{array}$ \\
\hline 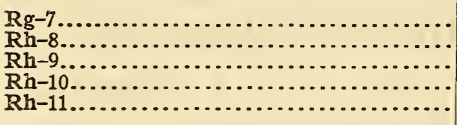 & $\begin{array}{l}62.70 \\
57.70 \\
52.70 \\
47.70 \\
42.70\end{array}$ & $\begin{array}{l}36.96 \\
36.96 \\
36.96 \\
36.96 \\
36.96\end{array}$ & $\begin{array}{l}6.95 \\
6.95 \\
6.95 \\
6.95 \\
6.95\end{array}$ & $\begin{array}{l}15.51 \\
15.51 \\
15.51 \\
15.51 \\
15.51\end{array}$ & $\begin{array}{r}5.00 \\
10.00 \\
15.00 \\
20.00\end{array}$ & $\begin{array}{l}\ldots \ldots \\
\ldots \ldots \ldots \\
\ldots \ldots \ldots \\
\ldots \ldots \ldots\end{array}$ \\
\hline $\begin{array}{l}\mathrm{Rh}-12 \ldots \ldots \ldots \\
\mathrm{Rh}-13 \ldots \ldots \ldots \\
\mathrm{Rh}-14 \ldots \ldots \\
\mathrm{Rh}-15 \ldots \ldots \ldots\end{array}$ & $\begin{array}{l}57.70 \\
52.70 \\
47.70 \\
60.20\end{array}$ & $\begin{array}{l}36.96 \\
36.96 \\
36.96 \\
36.96\end{array}$ & $\begin{array}{l}6.95 \\
6.95 \\
6.95 \\
6.95\end{array}$ & $\begin{array}{l}20.51 \\
25.71 \\
30.81 \\
15.20\end{array}$ & (n...... & a.... \\
\hline $\begin{array}{l}\mathrm{Rh}-16 \ldots \ldots \\
\mathrm{Rh}-17 \ldots \ldots \ldots \\
\mathrm{Rh}-14 \mathrm{a} \\
\mathrm{Rh}-14 \mathrm{~b} \ldots \ldots \ldots\end{array}$ & $\begin{array}{l}57.70 \\
55.20 \\
42.70 \\
37.70\end{array}$ & $\begin{array}{l}36.96 \\
36.96 \\
36.96 \\
36.96\end{array}$ & $\begin{array}{l}6.95 \\
6.95 \\
6.95 \\
6.95\end{array}$ & $\begin{array}{l}15.20 \\
15.20 \\
35.92 \\
41.02\end{array}$ & 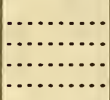 & $\begin{array}{r}8.85 \\
13.27 \\
\ldots \ldots . . .6 \\
\ldots .6 .6 .\end{array}$ \\
\hline
\end{tabular}

TABLE 6 C.-Effect of Varying Flint and Cryolite in Colored Enamels Based on Rg-7. [Constant portion melted, $13.57 \mathrm{~B}_{2} \mathrm{O}_{3}, 8.53 \mathrm{Na}: \mathrm{O}, 15.20 \mathrm{PbO}$.]

\begin{tabular}{|c|c|c|c|c|}
\hline \multirow{2}{*}{ Enamel number. } & \multicolumn{2}{|c|}{ Variables. } & \multicolumn{2}{|c|}{ Results. } \\
\hline & Flint. & Cryolite. & Texture. & Adherence. \\
\hline 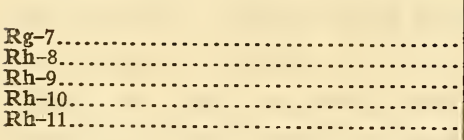 & $\begin{array}{r}\text { Per cent. } \\
62.7 \\
57.7 \\
52.7 \\
47.7 \\
42.7\end{array}$ & $\begin{array}{r}\text { Per cent. } \\
5.0 \\
10.0 \\
15.0 \\
20.0\end{array}$ & 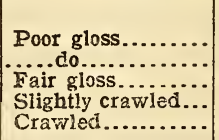 & $\begin{array}{l}\text { Chipped on edge. } \\
\text { Good. } \\
\text { Do. } \\
\text { Do. } \\
\text { Do. }\end{array}$ \\
\hline
\end{tabular}


TABLE 6 D.-Effect of Varying Flint and Lead Oxide in Colored Enamels Based on $\mathrm{Rg}-7$.

[Constant portion melted, $13.57 \mathrm{~B}_{2} \mathrm{O}_{3}, 8.53 \mathrm{Na}_{2} \mathrm{O}$.]

\begin{tabular}{|c|c|c|c|c|}
\hline \multirow{2}{*}{ Enamel number. } & \multicolumn{2}{|c|}{ Variables. } & \multicolumn{2}{|c|}{ Results. } \\
\hline & Flint. & $\mathrm{PbO}$. & Texture. & Adherence. \\
\hline 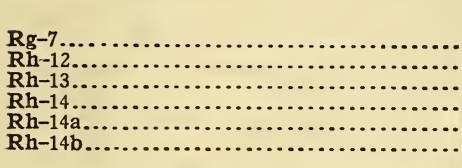 & \begin{tabular}{r|} 
Per cent. \\
62.7 \\
57.7 \\
52.7 \\
47.7 \\
42.7 \\
37.7
\end{tabular} & $\begin{array}{r}\text { Per cent. } \\
15.20 \\
20.20 \\
25.20 \\
30.20 \\
35.20 \\
40.20\end{array}$ & 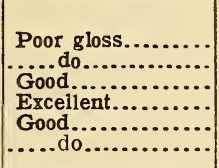 & $\begin{array}{l}\text { Chipped on edge. } \\
\text { Do. } \\
\text { Good. } \\
\text { Do. } \\
\text { Do. } \\
\text { Do. }\end{array}$ \\
\hline
\end{tabular}

TABLE 6 E.-Effect of Varying Flint and Boric Oxide in Colored Enamels Based on $\mathrm{Rg}-7$.

[Constant portion melted, $8.53 \mathrm{Na}_{2} \mathrm{O}, 15.20 \mathrm{PbO}$.]

\begin{tabular}{|c|c|c|c|c|}
\hline \multirow{2}{*}{ Enamel number. } & \multicolumn{2}{|c|}{ Variables. } & \multicolumn{2}{|c|}{ Results. } \\
\hline & Flint. & $\mathrm{B}_{2} \mathrm{O}_{3}$ & Texture. & Adherence. \\
\hline 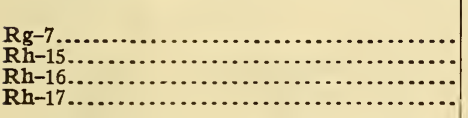 & \begin{tabular}{r|} 
Per cent. \\
62.7 \\
60.2 \\
57.7 \\
55.2
\end{tabular} & \begin{tabular}{r|} 
Per cent. \\
13.57 \\
16.07 \\
18.57 \\
21.07
\end{tabular} & 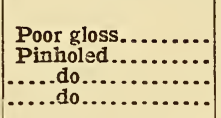 & $\begin{array}{l}\text { Chipped on edge. } \\
\text { Do. } \\
\text { Do. } \\
\text { Good. }\end{array}$ \\
\hline
\end{tabular}

TABLE 7 A.-Melted Compositions of Frits for Colored Enamels Based on Composition $\mathrm{Rg}-4 \mathrm{a}$.

\begin{tabular}{|c|c|c|c|c|c|}
\hline \multirow{2}{*}{ Enamel number. } & \multicolumn{5}{|c|}{ Melted compositions of frits. } \\
\hline & Feldspar. & $\mathrm{B}_{2} \mathrm{O}_{3}$ & $\mathrm{Na}_{2} \mathrm{O}$ & $\mathrm{PbO}$ & Cryolite. \\
\hline 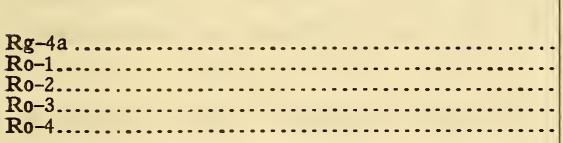 & $\begin{array}{r}\text { Per cent. } \\
62.05 \\
57.05 \\
52.05 \\
47.05 \\
42.05\end{array}$ & $\begin{array}{r}\text { Per cent. } \\
23.56 \\
23.56 \\
23.56 \\
23.55 \\
23.56\end{array}$ & \begin{tabular}{|r|} 
Per cent. \\
12.13 \\
12.13 \\
12.13 \\
12.13 \\
12.13
\end{tabular} & \begin{tabular}{r|} 
Per cent. \\
2.26 \\
2.26 \\
2.26 \\
2.26 \\
2.26
\end{tabular} & $\begin{array}{r}\text { Per cent. } \\
5.00 \\
10.00 \\
15.00 \\
20.00\end{array}$ \\
\hline 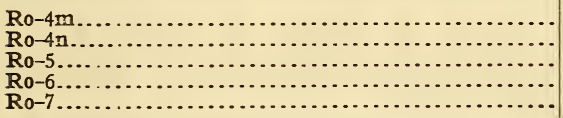 & $\begin{array}{l}4205 \\
37.05 \\
47.05 \\
47.05 \\
47.05\end{array}$ & $\begin{array}{r}23.56 \\
23.56 \\
18.56 \\
13.56 \\
8.56\end{array}$ & $\begin{array}{l}12.13 \\
12.13 \\
12.13 \\
12.13 \\
12.13\end{array}$ & $\begin{array}{l}22.26 \\
27.26 \\
22.26 \\
27.26 \\
32.26\end{array}$ & \begin{tabular}{|l}
$\ldots \ldots \ldots \ldots$ \\
$\ldots \ldots \ldots \ldots \ldots$ \\
$\ldots \ldots \ldots \ldots$ \\
$\ldots \ldots \ldots \ldots$ \\
$\ldots \ldots \ldots \ldots$
\end{tabular} \\
\hline
\end{tabular}

TABLE 7 B.-Batch Compositions of Frits for Colored Enamels Based on Composition $\mathrm{Rg}-4 \mathrm{a}$.

\begin{tabular}{|c|c|c|c|c|c|c|}
\hline \multirow{2}{*}{ Enamel number. } & \multicolumn{6}{|c|}{ Batch compositions for 100 parts of melted frit. } \\
\hline & Teldspar. & Borax. & $\begin{array}{l}\text { Sodium } \\
\text { nitrate. }\end{array}$ & $\begin{array}{l}\text { Red } \\
\text { lead. }\end{array}$ & Cryolite. & $\begin{array}{l}\text { Soda } \\
\text { ash. }\end{array}$ \\
\hline 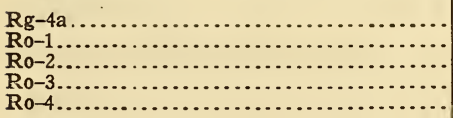 & $\begin{array}{l}62.05 \\
57.05 \\
52.05 \\
47.05 \\
42.05\end{array}$ & $\begin{array}{l}64.30 \\
64.30 \\
64.30 \\
64.30 \\
64.30\end{array}$ & $\begin{array}{l}4.63 \\
4.63 \\
4.63 \\
4.63 \\
4.63\end{array}$ & $\begin{array}{l}2.30 \\
2.30 \\
2.30 \\
2.30 \\
2.30\end{array}$ & $\begin{array}{r}5.00 \\
10.00 \\
15.00 \\
20.00\end{array}$ & $\mid \begin{array}{l}\cdots \ldots \\
\ldots \ldots \\
\cdots \ldots \ldots \\
\cdots \ldots \ldots \\
\cdots \ldots \ldots\end{array}$ \\
\hline 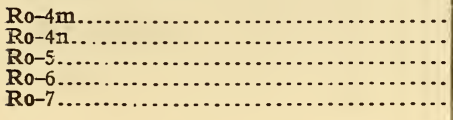 & $\begin{array}{l}42.05 \\
37.05 \\
47.05 \\
47.05 \\
47.05\end{array}$ & $\begin{array}{l}64.30 \\
64.30 \\
50.57 \\
36.94 \\
23.32\end{array}$ & $\begin{array}{l}4.63 \\
4.63 \\
4.63 \\
4.63 \\
4.63\end{array}$ & $\begin{array}{l}22.71 \\
27.81 \\
22.71 \\
27.81 \\
32.92\end{array}$ & \begin{tabular}{|l}
$\ldots \ldots \ldots$ \\
$\ldots \ldots \ldots$ \\
$\ldots \ldots \ldots$ \\
$\ldots \ldots \ldots$ \\
$\ldots \ldots \ldots$
\end{tabular} & $\begin{array}{r}\ldots .90 \\
3.90 \\
7.64 \\
11.42\end{array}$ \\
\hline
\end{tabular}


TABLE 7 C.-Effect of Varying Feldspar and Cryolite in Colored Enamels Based on $\mathrm{Rg}-4 \mathrm{a}$.

[Constant portion melted, $\left.23.56 \mathrm{~B}_{2} \mathrm{O}_{3}, 12.13 \mathrm{Na}_{2} \mathrm{O}, 2.26 \mathrm{PbO}.\right]$

\begin{tabular}{|c|c|c|c|c|}
\hline \multirow{2}{*}{ Enamel number. } & \multicolumn{2}{|c|}{ Variables. } & \multicolumn{2}{|c|}{ Results. } \\
\hline & Feldspar. & Cryolite. & Texture. & Adherence. \\
\hline 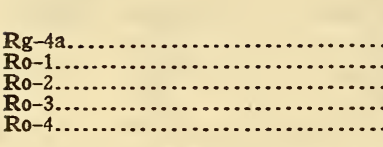 & $\begin{array}{r}\text { Per cent. } \\
62.05 \\
57.05 \\
52.05 \\
47.05 \\
42.05\end{array}$ & $\begin{array}{r}\text { Per cent. } \\
5.00 \\
10.00 \\
15.00 \\
20.00\end{array}$ & 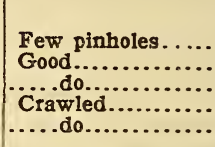 & $\begin{array}{l}\text { Good. } \\
\text { Do. } \\
\text { Do. } \\
\text { Do. } \\
\text { Do. }\end{array}$ \\
\hline
\end{tabular}

TABLE 7 D.-Effect of Varying Boric Oxide and Lead Oxide in Colored Enamels Based on Rg-4a.

[Constant portion melted, 47.05 feldspar, $\left.12.13 \mathrm{Na}_{2} \mathrm{O}.\right]$

\begin{tabular}{|c|c|c|c|c|}
\hline \multirow{2}{*}{ Enamel number. } & \multicolumn{2}{|c|}{ Variables. } & \multicolumn{2}{|c|}{ Results. } \\
\hline & $\mathrm{B}_{2} \mathrm{O}_{3}$. & Pbo. & Terture. & Adherence. \\
\hline 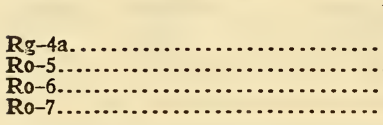 & \begin{tabular}{|r|} 
Per cent. \\
23.56 \\
18.56 \\
13.56 \\
8.56
\end{tabular} & $\begin{array}{r}\text { Per cent. } \\
17.26 \\
22.56 \\
27.26 \\
32.26\end{array}$ & $\begin{array}{l}\text { Few pinholes..... } \\
\text { Excellent........... } \\
\text { E...do.............. } \\
\ldots \ldots \text { do }\end{array}$ & $\begin{array}{l}\text { Good. } \\
\text { Do. } \\
\text { Do. } \\
\text { Do. }\end{array}$ \\
\hline
\end{tabular}

The most satisfactory enamel obtained in this series was Rh-I 4 . In this composition 5 per cent of flint was replaced by lead oxide. The enamel had an excellent gloss and was comparatively free from pinholes. When the lead oxide was increased beyond this point, however, as in Rh-I $4 \mathrm{a}$ and $\mathrm{I} 4 \mathrm{~b}$, no further improvement could be noted.

(c) REPLACEMENT OF FLINT By Boric OXIDE.-The effect of the replacement of flint by boric oxide is shown in Table $6 \mathrm{E}$. The results obtained in this series were not satisfactory, as the formation of pinholes was increased and the adherence was not improved to any appreciable extent. It was noted, however, that the boric oxide increased the gloss. Increasing the boric oxide 5 per cent at the expense of flint, as in $\mathrm{Rh}-\mathrm{I} 5$, slightly increased the gloss, but the enamel developed pinholes in firing and the adherence was not improved over $\mathrm{Rg}-7$. The results obtained with $\mathrm{Rh}-\mathrm{I} 6$ compared very closely to those of $\mathrm{Rh}-\mathrm{r} 5$, as both enamels developed pinholes and chipping. Rh-I6 apparently had good adherence but showed a tendency to crawl and to develop pinholes. Undoubtedly these compositions were too viscous for enamels of this type. 


\section{EFFECT OF VARYING COMPOSITIONS BASED ON ENAMEL Rg-4a.}

Tables $7 \mathrm{C}$ and $\mathrm{D}$ show compositions based on the feldspar type of enamels. This type, as a whole, appeared to be more suitable for the wet-process enamels and several very good enamels were obtained. Such enamels had a longer firing range, thus facilitating the process of firing.

(a) Replacement OF Feldspar By CRyolite.-Table $7 \mathrm{C}$ shows the effect of replacing feldspar by cryolite. Although several very satisfactory enamels were developed in this series, it would appear that the amount of cryolite contained in this composition should be limited to ro per cent if crawling is to be avoided. Increasing the cryolite 5 to ro per cent at the expense of feldspar, as in Ro-I and 2, respectively, produced enamels with good texture and adherence. Little difference could be noted between these two compositions. However, when feldspar was replaced by cryolite in amounts to 15 and 20 per cent, as in Ro- 3 and 4 , crawling occurred.

(b) Replacement of Boric Oxide by Lead Oxide.-In Table $7 \mathrm{D}$ is shown the effect of increasing lead oxide at the expense of boric oxide. The results obtained in this series were very favorable. The increase of lead oxide was beneficial from all viewpoints in that the texture was satisfactory and the adherence was improved. Replacing 5 per cent of boric oxide, as in Ro-5, produced an enamel with very good texture and adherence. Increasing the lead oxide ro and 15 per cent at the expense of boric oxide, as in Ro-6 and 7, gave practically the same results as were obtained with enamel Ro-5, except that the increase of lead oxide produced more fusible compositions.

\section{CONCLUSIONS FROM STUDY OF SINGLE-COAT COLORED ENAMELS.}

In discussing the data from the above study of colored enamels no mention has been made of the shades of color that were obtained, inasmuch as the length of time of firing affected to some extent the intensity of color. The different compositions, however, apparently had no effect on the color produced with this particular blue oxide.

In making the study of colored enamels one coat was applied to one-half the number of trial samples, and two coats were applied to the remainder, this method being adopted to note the effect of several applications of the same enamel on its burning 
behavior. But little difference was noted in the results obtained with one and with two coats, except in the case of those enamels which showed a tendency to develop blistering. The ability of an enamel of this type to take a second coat satisfactorily is a decided advantage in commercial practice, where it is at times necessary to rectify variations in shade of color, due to uneven spraying or to overfiring, by the application of a second coat of the enamel

The effects of the various ingredients of the enamels were similar to those noted in the development of cover enamels applied over a ground coat. Cryolite and boric oxide increased the viscosity of the enamel and tended to cause crawling. Lead oxide increased the gloss and promoted better adherence to the iron, and enamels containing as much as 30 to 40 per cent of lead oxide in the melted batch were found to be very satisfactory.

In the type of enamels containing flint as the refractory an enamel with the composition of $\mathrm{Rh}-\mathrm{I} 4$ or I4a should be very satisfactory.

Single-coat enamels of the feldspar type, however, are apparently more satisfactory than those containing flint as the sole refractory. In this group enamels Ro-5, 6, and 7 gave best results.

Mill additions of 4 per cent of clay, I per cent of coloring oxide, and 45 per cent of water are satisfactory. When rusting of the iron is encountered in the drying of the enamels on the casting, small additions of borax may be made to the mill batch.

The following compositions are typical of those which should serve as single-coat colored enamels on cast iron:

Frits for Single-Coat Colored Enamels.

\begin{tabular}{|c|c|c|c|c|}
\hline \multirow{2}{*}{ Material. } & \multicolumn{4}{|c|}{$\begin{array}{l}\text { Batch compositions to give } 100 \text { parts of } \\
\text { melted frit. }\end{array}$} \\
\hline & Rh-14. & Ro-5. & Ro-6. & Ro-7. \\
\hline 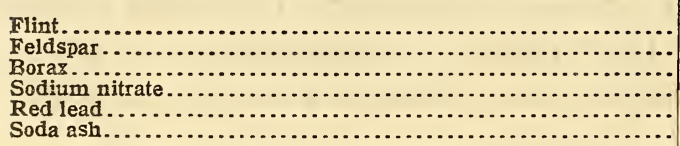 & $\begin{array}{r}47.70 \\
36.96 \\
6.95 \\
30.81 \\
3 .\end{array}$ & $\begin{array}{r}47.05 \\
50.57 \\
4.63 \\
22.71 \\
3.90\end{array}$ & $\begin{array}{r}37.05 \\
36.94 \\
4.63 \\
22.71 \\
7.64\end{array}$ & $\begin{array}{r}77.05 \\
23.32 \\
4.63 \\
22.71 \\
11.42\end{array}$ \\
\hline
\end{tabular}

Mill Batch for Single-Coat Enamels.

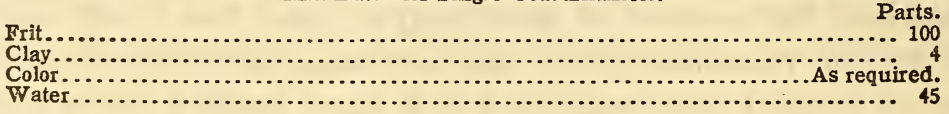




\section{STUDY OF SINGLE-COAT WHITE ENAMELS.}

\section{BASIC COMPOSITIONS FOR STUDY.}

In studying white enamels it was decided to adopt Ro-5, one of the more promising compositions produced in the development of colored enamels, and make such variations in the composition as might be expected to produce opacity. It was desired to produce as much opacity in the raw frit as possible, since it was noted that an excessive amount of tin oxide in the mill mix had a tendency to produce black specks, probably due to the reduction of the tiin oxide. The mill additions consisted of 4 per cent of tin oxide, 4 per cent of clay, and the necessary amount of water. Such materials as cryolite, fluorspar, zirconium compounds, and antimony oxide were, therefore, introduced to improve opacity.

\section{EFFECT OF VARYING COMPOSITIONS.}

Tables $8 \mathrm{~A}$ and $\mathrm{B}$ show the melted and the batch weights of 33 compositions. As in the previous study on colored enamels, it was possible to divide the various compositions into series as shown in Tables $8 \mathrm{C}$ to $\mathrm{M}$.

(a) Replacement of Feldspar by Cryolite.-In Table $8 \mathrm{C}$ is shown the effect of replacing feldspar by cryolite. The results obtained in this series were not as satisfactory as might be expected, since the cryolite did not produce the desired opacity, and the compositions with the higher content showed a decided tendency to crawl. Ro-8 and 9, containing 3 and 6 per cent of cryolite, respectively, possessed a very good texture and satisfactory adherence, but no appreciable opacity could be noted. Increasing the cryolite to 9 and $\mathrm{I} 2$ per cent, as in Ro-ro and II, produced enamels with poor opacity and showing a decided tendency to crawl.

(b) REPLACEMENT OF FELdSPAR By Zinc OxidE.--The effect of increasing zinc oxide at the expense of feldspar is shown in Table $8 \mathrm{D}$. These compositions showed an increase of opacity over Ro-5. Apparently there was no increase of opacity when more than 6 per cent of zinc oxide was added. It was also noted that crawling occurred when the zinc oxide was increased beyond this amount.

The most satisfactory results were obtained with Ro-I 2 and I 3 , containing 3 and 6 per cent of zinc oxide. Although the opacity of these compositions was not as great as it was hoped to obtain, 
they would, however, serye very well for a light gray enamel. Compositions Ro-r 4 and 15 did not show any increase of opacity and crawled badly.

(c) Replaceiment of Feldspar by Antimony Oxide.-Table $8 \mathrm{E}$ shows the effect of replacing feldspar by antimony oxide. The results obtained in this study were very promising. Antimony oxide produced quite an increase in opacity, but at the same time the resultant enamels did not possess the usual gloss of the average cast-iron enamel. The best results were obtained with Ro-I6 and I7. The opacity of these compositions compared fairly well with those of the previous study in connection with the use of a ground coat. When the antimony oxide was increased to 6 and 8 per cent, as in Ro-I 8 and I9, black specks were apparent and no increase in opacity could be observed. The most objectionable feature in the use of antimony oxide with this type of enamel was the tendency to produce a greasy finish.

TABLB 8 A.-Melted Compositions of Single-Coat White Enamels.

\begin{tabular}{|c|c|c|c|c|c|c|c|c|c|}
\hline \multirow{2}{*}{$\begin{array}{l}\text { Enamel } \\
\text { number. }\end{array}$} & \multicolumn{9}{|c|}{ Melted composition of frit. } \\
\hline & Feldspar. & $\mathrm{B}_{2} \mathrm{O}_{3}$. & $\mathrm{Na}_{2} \mathrm{O}$. & PbO. & $\mathrm{Sb}_{2} \mathrm{O}_{3}$ & $\mathrm{ZnO}$. & $\mathrm{ZrO}_{2}$ & Cryolite. & $\mathrm{CaF}_{2}$ \\
\hline $\begin{array}{l}\text { Ro-8......... } \\
\text { Ro-9........ } \\
\text { Ro-10....... } \\
\text { Ro-11........ } \\
\text { Ro-12....... }\end{array}$ & \begin{tabular}{|r|} 
Per cent. \\
44.05 \\
41.05 \\
38.05 \\
35.05 \\
44.05
\end{tabular} & \begin{tabular}{|r|} 
Per cent. \\
18.56 \\
18.56 \\
18.56 \\
18.56 \\
18.56
\end{tabular} & \begin{tabular}{|r|} 
Per cent. \\
12.13 \\
12.13 \\
12.13 \\
12.13 \\
12.13
\end{tabular} & $\begin{array}{r}\text { Per cent. } \\
22.26 \\
22.26 \\
22.26 \\
22.26 \\
22.26\end{array}$ & \begin{tabular}{c} 
Per cent. \\
\hdashline$\ldots \ldots$ \\
\hdashline$\ldots \ldots$ \\
\hdashline$\cdots$ \\
\hdashline$\cdots$ \\
$\cdots$
\end{tabular} & \begin{tabular}{|} 
Per cent. \\
\hdashline \\
\hdashline \\
\hdashline \\
\hdashline
\end{tabular} & \begin{tabular}{l} 
Per cent. \\
\hdashline$\cdots$ \\
\hdashline$\ldots$ \\
\hdashline \\
\hdashline
\end{tabular} & $\begin{array}{r}\text { Per cent. } \\
3.00 \\
6.00 \\
9.00 \\
12.00 \\
\ldots . . . . . .\end{array}$ & 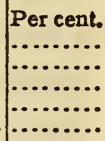 \\
\hline $\begin{array}{l}\text { Ro-13........ } \\
\text { Ro-14........ } \\
\text { Ro-15........ } \\
\text { Ro-16........ } \\
\text { Ro-17...... }\end{array}$ & $\begin{array}{l}41.05 \\
38.05 \\
35.05 \\
45.05 \\
43.05\end{array}$ & $\begin{array}{l}18.56 \\
18.56 \\
18.56 \\
18.56 \\
18.56\end{array}$ & $\begin{array}{l}12.13 \\
12.13 \\
12.13 \\
12.13 \\
12.13\end{array}$ & $\begin{array}{l}22.26 \\
22.26 \\
22.26 \\
22.26 \\
22.26\end{array}$ & \begin{tabular}{r}
$\cdots$ \\
$\cdots \cdots$ \\
\hdashline .00 \\
4.00
\end{tabular} & $\begin{array}{r}6.00 \\
9.00 \\
12.00 \\
\cdots \cdots \\
\cdots \\
\cdots\end{array}$ & $\begin{array}{l}\because . \\
\because \\
\because \\
\because \\
.\end{array}$ & $\begin{array}{l}\because . \\
\because \\
\because \\
\therefore\end{array}$ & $\begin{array}{l}\ldots \ldots \\
\ldots \ldots \\
\cdots \cdots\end{array}$ \\
\hline $\begin{array}{l}\text { Ro-18........ } \\
\text { Ro-19....... } \\
\text { Ro } 0-20 \ldots . . . \\
\text { Ro-21........ } \\
\mathbf{R}_{0}-22 \ldots . . .\end{array}$ & $\begin{array}{l}41.05 \\
39.05 \\
45.05 \\
43.05 \\
41.05\end{array}$ & $\begin{array}{l}18.56 \\
18.56 \\
18.56 \\
18.56 \\
18.56\end{array}$ & $\begin{array}{l}12.13 \\
12.13 \\
12.13 \\
12.13 \\
12.13\end{array}$ & $\begin{array}{l}22.26 \\
22.26 \\
22.26 \\
22.26 \\
22.26\end{array}$ & 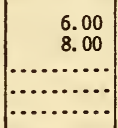 & & $\begin{array}{l}\ldots \ldots . \\
2.00 \\
4.00 \\
6.00\end{array}$ & & 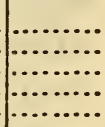 \\
\hline $\begin{array}{l}\text { Ro-23........ } \\
\text { Ro-24....... } \\
\text { Ro-25....... } \\
\text { Ro } 26 \ldots . . . . \\
\text { Ro } 27 . . . . .\end{array}$ & $\begin{array}{l}39.05 \\
45.05 \\
43.05 \\
41.05 \\
43.05\end{array}$ & $\begin{array}{l}18.56 \\
18.56 \\
18.56 \\
18.56 \\
18.56\end{array}$ & $\begin{array}{l}12.13 \\
12.13 \\
12.13 \\
12.13 \\
12.13\end{array}$ & $\begin{array}{l}22.26 \\
22.26 \\
22.26 \\
22.26 \\
22.26\end{array}$ & $\begin{array}{c}1.00 \\
2.00 \\
3.00 \\
\cdots \cdots\end{array}$ & & $\begin{array}{l}8.00 \\
1.00 \\
2.00 \\
3.00 \\
1.00\end{array}$ & 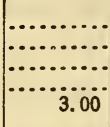 & $\begin{array}{l}\cdots \ldots \ldots \ldots \\
\cdots \ldots \ldots \ldots \\
\cdots \ldots \ldots \ldots \\
\cdots \ldots \ldots\end{array}$ \\
\hline $\begin{array}{l}\text { Ro-28....... } \\
\text { Ro-29....... } \\
\text { Ro-30....... } \\
\text { Ro-31....... }\end{array}$ & $\begin{array}{l}39.05 \\
35.05 \\
43.05 \\
39.05\end{array}$ & $\begin{array}{l}18.56 \\
18.56 \\
18.56 \\
18.56\end{array}$ & $\begin{array}{l}12.13 \\
12.13 \\
12.13 \\
12.13\end{array}$ & $\begin{array}{l}22.26 \\
22.26 \\
22.26 \\
22.26\end{array}$ & $\begin{array}{r}1.00 \\
2.00\end{array}$ & $\begin{array}{l}\cdots \\
\cdots \cdots \\
\cdots \cdots\end{array}$ & $\mid \begin{array}{r}2.00 \\
3.00 \\
\cdots \ldots \ldots \ldots \\
\cdots \ldots . \cdots\end{array}$ & $\begin{array}{l}6.00 \\
9.00 \\
3.00 \\
6.00\end{array}$ & $\begin{array}{l}\ldots \ldots \ldots \ldots \\
\ldots \ldots \ldots \ldots \\
\ldots \ldots \ldots \ldots \\
\ldots \ldots \ldots\end{array}$ \\
\hline $\begin{array}{l}\text { Ro-32....... } \\
\text { Ro-33........ } \\
\text { Ro-34....... } \\
\text { Ro-35....... }\end{array}$ & $\begin{array}{l}35.05 \\
41.05 \\
38.05 \\
41.05\end{array}$ & $\begin{array}{l}18.56 \\
18.56 \\
18.56 \\
18.56\end{array}$ & $\begin{array}{l}12.13 \\
12.13 \\
12.13 \\
10.13\end{array}$ & $\begin{array}{l}22.26 \\
22.26 \\
22.26 \\
22.26\end{array}$ & 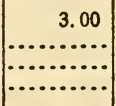 & & 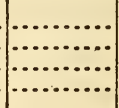 & $\begin{array}{l}9.00 \\
3.00 \\
3.00 \\
3.00\end{array}$ & $\begin{array}{l}3.00 \\
6.00 \\
3.00\end{array}$ \\
\hline $\begin{array}{l}\text { Ro-36....... } \\
\text { Ro-37....... } \\
\text { Ro-38....... } \\
\mathbf{R}_{0}-39 . . . . .\end{array}$ & $\begin{array}{l}38.05 \\
45.05 \\
45.05 \\
45.05\end{array}$ & $\begin{array}{l}18.56 \\
16.56 \\
14.56 \\
12.56\end{array}$ & $\begin{array}{l}10.13 \\
12.13 \\
12.13 \\
12.13\end{array}$ & $\begin{array}{l}22.26 \\
22.26 \\
22.26 \\
22.26\end{array}$ & $\begin{array}{l}2.00 \\
2.00 \\
2.00 \\
2.00\end{array}$ & & 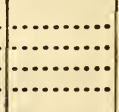 & $\begin{array}{l}3.00 \\
2.00 \\
4.00 \\
6.00\end{array}$ & 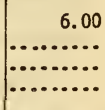 \\
\hline
\end{tabular}


TABLE 8 B.-Batch Weights of Single-Coat White Enamels.

\begin{tabular}{|c|c|c|c|c|c|c|c|c|c|c|}
\hline \multirow{2}{*}{$\begin{array}{l}\text { Enamel. } \\
\text { number. }\end{array}$} & \multicolumn{10}{|c|}{ Batch compositions for 100 parts of melted frit. } \\
\hline & $\begin{array}{l}\text { Feld- } \\
\text { spar. }\end{array}$ & Borax. & $\begin{array}{l}\text { Sodium } \\
\text { nitrate. }\end{array}$ & $\begin{array}{l}\text { Red } \\
\text { lead. }\end{array}$ & $\begin{array}{l}\text { Soda } \\
\text { ash. }\end{array}$ & $\begin{array}{l}\text { Anti- } \\
\text { mony } \\
\text { oxide. }\end{array}$ & $\begin{array}{c}\text { Zinc } \\
\text { oxide. }\end{array}$ & $\begin{array}{c}\text { Zircon- } \\
\text { ium } \\
\text { oxide. }\end{array}$ & $\begin{array}{l}\text { Cryo- } \\
\text { lite. }\end{array}$ & $\begin{array}{l}\text { Fluor- } \\
\text { spar. }\end{array}$ \\
\hline $\begin{array}{l}\text { Ro-8........ } \\
\text { Ro-9....... } \\
\text { Ro-10...... } \\
\text { Ro-11....... } \\
\text { Ro-12....... }\end{array}$ & $\begin{array}{l}44.05 \\
41.05 \\
38.05 \\
35.05 \\
44.05\end{array}$ & $\begin{array}{l}50.57 \\
50.57 \\
50.57 \\
50.57 \\
50.57\end{array}$ & $\begin{array}{l}4.63 \\
4.63 \\
4.63 \\
4.63 \\
4.63\end{array}$ & $\begin{array}{l}22.71 \\
22.71 \\
22.71 \\
22.71 \\
22.71\end{array}$ & $\begin{array}{l}3.85 \\
3.85 \\
3.85 \\
3.85 \\
3.85\end{array}$ & & & & $\begin{array}{r}3.00 \\
6.00 \\
9.00 \\
12.00 \\
\ldots . . . .\end{array}$ & $\begin{array}{l}\cdots \cdot . \\
\cdots \cdot \\
\cdots \cdot \\
\cdots\end{array}$ \\
\hline $\begin{array}{l}\text { Ro-13...... } \\
\text { Ro-14....... } \\
\text { Ro-15...... } \\
\text { Ro-16...... } \\
\text { Ro-17....... }\end{array}$ & $\begin{array}{l}41.05 \\
38.05 \\
35.05 \\
45.05 \\
43.05\end{array}$ & $\begin{array}{l}50.57 \\
50.57 \\
50.57 \\
50.57 \\
50.57\end{array}$ & $\begin{array}{l}4.63 \\
4.63 \\
4.63 \\
4.63 \\
4.63\end{array}$ & $\begin{array}{l}22.71 \\
22.71 \\
22.71 \\
22.71 \\
22.71\end{array}$ & $\begin{array}{l}3.85 \\
3.85 \\
3.85 \\
3.85 \\
3.85\end{array}$ & $\begin{array}{r}2.00 \\
4.00\end{array}$ & $\begin{array}{r}6.00 \\
9.00 \\
12.00 \\
\ldots . . .\end{array}$ & & & $\begin{array}{l}\cdots \\
\cdots \\
\cdots \\
\cdots\end{array}$ \\
\hline $\begin{array}{l}\text { Ro-18....... } \\
\text { Ro-19....... } \\
\text { Ro-20....... } \\
\text { Ro-21....... } \\
\text { Ro-22 ....... }\end{array}$ & $\begin{array}{l}41.05 \\
39.05 \\
45.05 \\
43.05 \\
41.05\end{array}$ & $\begin{array}{l}50.57 \\
50.57 \\
50.57 \\
50.57 \\
50.57\end{array}$ & $\begin{array}{l}4.63 \\
4.63 \\
4.63 \\
4.63 \\
4.63\end{array}$ & $\begin{array}{l}22.71 \\
22.71 \\
22.71 \\
22.71 \\
22.71\end{array}$ & $\begin{array}{l}3.85 \\
3.85 \\
3.85 \\
3.85 \\
3.85\end{array}$ & $\begin{array}{r}6.00 \\
8.00 \\
\end{array}$ & & $\begin{array}{l}2.00 \\
4.00 \\
6.00\end{array}$ & $\begin{array}{l}\because \\
\because \\
\cdots \\
-\cdot \\
\end{array}$ & \begin{tabular}{l}
$\ldots$ \\
\hdashline$\ldots \ldots$ \\
\hdashline$\ldots \ldots$ \\
\hdashline$\ldots \ldots$
\end{tabular} \\
\hline $\begin{array}{l}\text { Ro-23...... } \\
\text { Ro-24 } \\
\text { Ro-25........ } \\
\text { Ro-266...... } \\
\text { Ro-27...... }\end{array}$ & $\begin{array}{l}39.05 \\
45.05 \\
43.05 \\
41.05 \\
43.05\end{array}$ & $\begin{array}{l}50.57 \\
50.57 \\
50.57 \\
50.57 \\
50.57\end{array}$ & $\begin{array}{l}4.63 \\
4.63 \\
4.63 \\
4.63 \\
4.63\end{array}$ & $\begin{array}{l}22.71 \\
22.71 \\
22.71 \\
22.71 \\
22.71\end{array}$ & $\begin{array}{l}3.85 \\
3.85 \\
3.85 \\
3.85 \\
3.85\end{array}$ & $\begin{array}{l}1.00 \\
2.00 \\
3.00\end{array}$ & & $\begin{array}{l}8.00 \\
1.00 \\
2.00 \\
3.00 \\
1.00\end{array}$ & 3.00 & 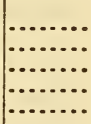 \\
\hline $\begin{array}{l}\text { Ro-28....... } \\
\text { Ro-29....... } \\
\text { Ro-30...... } \\
\text { Ro-31...... }\end{array}$ & $\begin{array}{l}39.05 \\
35.05 \\
43.05 \\
39.05\end{array}$ & $\begin{array}{l}50.57 \\
50.57 \\
50.57 \\
50.57\end{array}$ & $\begin{array}{l}4.63 \\
4.63 \\
4.63 \\
4.63\end{array}$ & $\begin{array}{l}22.71 \\
22.71 \\
22.71 \\
22.71\end{array}$ & $\begin{array}{l}3.85 \\
3.85 \\
3.85 \\
3.85\end{array}$ & $\begin{array}{l}1.00 \\
2.00\end{array}$ & & $\begin{array}{c}2.00 \\
3.00 \\
\ldots \ldots . . \\
\ldots . . .\end{array}$ & $\begin{array}{l}6.00 \\
9.00 \\
3.00 \\
6.00\end{array}$ & 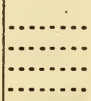 \\
\hline $\begin{array}{l}\text { Ro-32....... } \\
\text { Ro-33...... } \\
\text { Ro-34....... } \\
\text { Ro-35....... }\end{array}$ & $\begin{array}{l}35.05 \\
41.05 \\
38.05 \\
41.05\end{array}$ & $\begin{array}{l}50.57 \\
50.57 \\
50.57 \\
50.57\end{array}$ & $\begin{array}{l}4.63 \\
4.63 \\
4.63 \\
5.34\end{array}$ & $\begin{array}{l}22.71 \\
22.71 \\
22.71 \\
22.71\end{array}$ & $\begin{array}{r}3.85 \\
3.85 \\
3.85 \\
\ldots . . .\end{array}$ & $\begin{array}{r}3.00 \\
\cdots . . . . \\
2.00\end{array}$ & & & $\begin{array}{l}9.00 \\
3.00 \\
3.00 \\
3.00\end{array}$ & $\begin{array}{l}3.00 \\
6.00 \\
3.00\end{array}$ \\
\hline $\begin{array}{l}\text { Ro-36...... } \\
\text { Ro }-37 . \ldots . . . \\
\text { Ro } 38 . . . . \\
\text { Ro-39...... }\end{array}$ & $\begin{array}{l}38.05 \\
45.05 \\
45.05 \\
45.05\end{array}$ & $\begin{array}{l}50.57 \\
45.10 \\
39.67 \\
34.22\end{array}$ & $\begin{array}{l}5.34 \\
4.63 \\
4.63 \\
4.63\end{array}$ & $\begin{array}{l}22.71 \\
22.71 \\
22.71 \\
22.71\end{array}$ & $\begin{array}{l}7.36 \\
6.87 \\
8.39\end{array}$ & $\begin{array}{l}2.00 \\
2.00 \\
2.00 \\
2.00\end{array}$ & & & $\begin{array}{l}3.00 \\
2.00 \\
4.00 \\
6.00\end{array}$ & $\begin{array}{r}\quad 6.00 \\
\cdots .2 . \\
\ldots .2 . \\
.2 .\end{array}$ \\
\hline
\end{tabular}

TABLE 8 C.-Effect of Varying Feldspar and Cryolite in Single-Coat White Enamels.

[Constant portion melted, 18.56 $\mathrm{B}_{2} \mathrm{O}_{3}, 12.13 \mathrm{Na}_{2} \mathrm{O}, 22.26 \mathrm{PbO}$.]

\begin{tabular}{|c|c|c|c|c|}
\hline \multirow{2}{*}{ Enamel number. } & \multicolumn{2}{|c|}{$\begin{array}{l}\text { Melted weights of } \\
\text { variables. }\end{array}$} & \multicolumn{2}{|l|}{ Results. } \\
\hline & Feldspar. & Cryolite. & Texture. & Opacity. \\
\hline 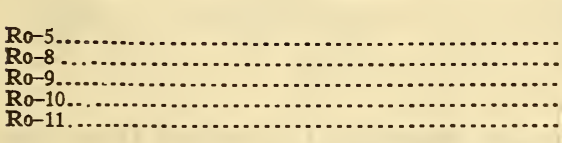 & $\begin{array}{r}\text { Per cent. } \\
47.05 \\
44.05 \\
41.05 \\
38.05 \\
35.05\end{array}$ & $\begin{array}{r}\text { Per cent. } \\
3.00 \\
6.00 \\
9.00 \\
12.00\end{array}$ & 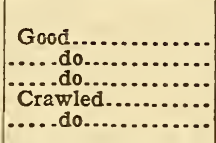 & $\begin{array}{l}\text { Poor. } \\
\text { Do. } \\
\text { Do. } \\
\text { Do. } \\
\text { Do. }\end{array}$ \\
\hline
\end{tabular}

TABLE 8 D.-Effect of Varying Feldspar and Zinc Oxide in White Single-Coat Enamels.

[Constant portion melted, 18.56 $\mathrm{B}_{2} \mathrm{O}_{3}, 12.13 \mathrm{Na}_{2} \mathrm{O}, 22.26 \mathrm{PbO}$.]

\begin{tabular}{|c|c|c|c|c|}
\hline \multirow{2}{*}{ Enamel number. } & \multicolumn{2}{|c|}{$\begin{array}{l}\text { Melted weights of } \\
\text { variables. }\end{array}$} & \multicolumn{2}{|l|}{ Results. } \\
\hline & Feldspar. & $\mathrm{ZnO}$. & Texture. & Opacity. \\
\hline 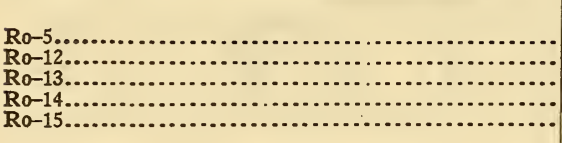 & \begin{tabular}{r|} 
Per cent. \\
47.05 \\
44.05 \\
41.05 \\
38.05 \\
35.05
\end{tabular} & $\begin{array}{r}\text { Per cent. } \\
3.00 \\
6.00 \\
9.00 \\
12.00\end{array}$ & 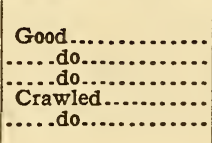 & $\begin{array}{l}\text { Poor. } \\
\text { Fair. } \\
\text { Do. } \\
\text { Do. } \\
\text { Do. }\end{array}$ \\
\hline
\end{tabular}


TABLE 8 E.-Effect of Varying Feldspar and Antimony Oxide in Single-Coat White Enamels.

[Constant portion melted, $18.56 \mathrm{~B}_{2} \mathrm{O}_{3}, 12.13 \mathrm{Na}_{2} \mathrm{O}, 22.26 \mathrm{PbO}$.]

\begin{tabular}{|c|c|c|c|c|}
\hline \multirow{2}{*}{ Enamel number. } & \multicolumn{2}{|c|}{$\begin{array}{l}\text { Melted weights of } \\
\text { variables. }\end{array}$} & \multicolumn{2}{|l|}{ Results. } \\
\hline & Feldspar. & $\mathrm{Sb}_{2} \mathrm{O}_{3}$ & Texture. & Opacity. \\
\hline 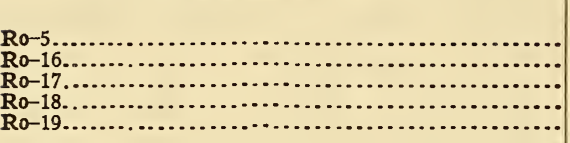 & $\begin{array}{r}\text { Per cent. } \\
47.05 \\
45.05 \\
43.05 \\
41.05 \\
39.05\end{array}$ & $\begin{array}{r}\text { Per cent. } \\
2.0 \\
4.0 \\
6.0 \\
8.0\end{array}$ & 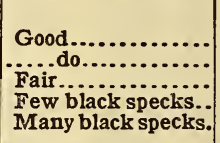 & $\begin{array}{l}\text { Poor. } \\
\text { Fair. } \\
\text { Do. } \\
\text { Do. } \\
\text { Do. }\end{array}$ \\
\hline
\end{tabular}

TABLE 8 F.-Effect of Varying Feldspar and Zirconium Oxide in Single-Coat White Enamels.

[Constant portion melted, 18.56 $\mathrm{B}_{2} \mathrm{O}_{3}, 12.13 \mathrm{Na}_{2} \mathrm{O}, 22.26 \mathrm{PbO}$.]

\begin{tabular}{|c|c|c|c|c|}
\hline \multirow{2}{*}{ Enamel number. } & \multicolumn{2}{|c|}{$\begin{array}{l}\text { Melted weights of } \\
\text { variables. }\end{array}$} & \multicolumn{2}{|l|}{ Results. } \\
\hline & Feldspar. & $\mathrm{ZrO}_{2}$ & Texture. & Opacity. \\
\hline $\begin{array}{l}\mathbf{R} 0-5 \ldots \\
\mathbf{R} 0-20 \\
\mathbf{R} 0-21 \\
\mathbf{R} 0-22 \\
\mathbf{R} 0-23 \ldots \ldots\end{array}$ & $\begin{array}{r}\text { Per cent. } \\
47.05 \\
45.05 \\
43.05 \\
41.05 \\
39.05\end{array}$ & $\begin{array}{r}\text { Per cent. } \\
2.0 \\
4.0 \\
6.0 \\
8.0\end{array}$ & 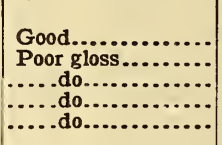 & $\begin{array}{l}\text { Poor. } \\
\text { Fair. } \\
\text { Do. } \\
\text { Do. } \\
\text { Do. }\end{array}$ \\
\hline
\end{tabular}

TABLE 8 G.-Effect of Varying Feldspar and Mixtures of Zirconium and Antimony Oxides in Single-Coat White Enamels.

[Constant portion melted, 18.56 $\mathrm{B}_{2} \mathrm{O}_{3}, 12.13 \mathrm{Na}_{2} \mathrm{O}, 22.26 \mathrm{PbO}$.]

\begin{tabular}{|c|c|c|c|c|c|}
\hline \multirow{2}{*}{ Enamel number. } & \multicolumn{3}{|c|}{ Melted weights of variables. } & \multicolumn{2}{|l|}{ Results. } \\
\hline & Feldspar. & $\mathrm{Z}_{\mathrm{rO}_{2}}$ & $\mathrm{Sb}_{2} \mathrm{O}_{3}$ & Texture. & Opacity. \\
\hline 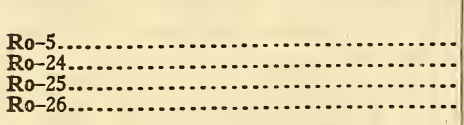 & \begin{tabular}{r|} 
Per cent. \\
47.05 \\
45.05 \\
43.05 \\
41.05
\end{tabular} & $\mid \begin{array}{r}\text { Per cent. } \\
1.0 \\
2.0 \\
3.0\end{array}$ & $\begin{array}{r}\text { Per cent. } \\
1.0 \\
2.0 \\
3.0\end{array}$ & 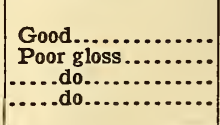 & $\begin{array}{l}\text { Poor. } \\
\text { Fair. } \\
\text { Do. } \\
\text { Do. }\end{array}$ \\
\hline
\end{tabular}

TABLE $8 \mathrm{H}$.-Effect of Varying Feldspar and Mixtures of Zirconium Oxide and Cryolite in Single-Coat White Enamels.

[Constant portion melted, 18.56 $\mathrm{B}_{2} \mathrm{O}_{3}, 12.13 \mathrm{Na}_{2} \mathrm{O}, 22.26 \mathrm{PbO}$.]

\begin{tabular}{|c|c|c|c|c|c|}
\hline \multirow{2}{*}{ Enamel number. } & \multicolumn{3}{|c|}{ Melted weights of variables. } & \multicolumn{2}{|l|}{ Results. } \\
\hline & Feldspar. & $\mathrm{ZrO}_{2}$ & Cryolite. & Texture. & Opacity. \\
\hline 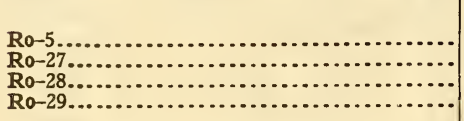 & \begin{tabular}{r|} 
Per cent. \\
47.05 \\
43.05 \\
39.05 \\
35.05
\end{tabular} & $\begin{array}{r}\text { Per cent. } \\
\text { 1.0. } \\
2.0 \\
3.0\end{array}$ & $\begin{array}{r}\text { Per cent. } \\
3.0 \\
6.0 \\
9.0\end{array}$ & 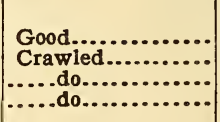 & $\begin{array}{c}\text { Poor. } \\
\text { Fair. } \\
\text { Do. } \\
\text { Do. }\end{array}$ \\
\hline
\end{tabular}


TABLE 8 I.-Effect of Varying Feldspar and Mixtures of Antimony Oxide and Cryolite in Single-Coat White Enamels.

[Constant portion melted, 18.56 $\mathrm{B}_{2} \mathrm{O}_{3}, 12.13 \mathrm{Na}_{2} \mathrm{O}, 22.26 \mathrm{PbO}$.]

\begin{tabular}{|c|c|c|c|c|c|}
\hline \multirow{2}{*}{ Enamel number. } & \multicolumn{3}{|c|}{ Melted weights of variables. } & \multicolumn{2}{|l|}{ Results. } \\
\hline & Feldspar. & $\mathrm{Sb}_{2} \mathrm{O}_{3}$ & Cryolite. & Texture. & Opacity. \\
\hline 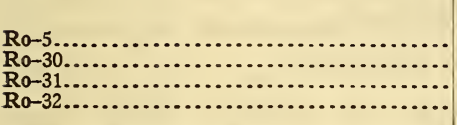 & $\begin{array}{r}\text { Per cent. } \\
47.05 \\
43.05 \\
39.05 \\
35.05\end{array}$ & $\begin{array}{r}\text { Per cent. } \\
1.0 \\
2.0 \\
3.0\end{array}$ & $\begin{array}{r}\text { Per cent. } \\
3.0 \\
6.0 \\
9.0\end{array}$ & 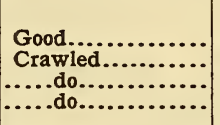 & $\begin{array}{c}\text { Poor. } \\
\text { Fair. } \\
\text { Do. } \\
\text { Do. }\end{array}$ \\
\hline
\end{tabular}

(d) Replacement of Fer Feldspar by Zirconium Oxide.-The effect of the replacement of feldspar by zirconium oxide is shown in Table $8 \mathrm{~F}$. In studying the effect of zirconium oxide in the wetprocess enamels it was noted that the refractoriness was slightly increased. This is characteristic of zirconium oxide, and it has been found to be true with various enamel compositions, both for sheet steel and cast iron. Practically the same results were obtained with zirconium oxide as with antimony oxide in the previous series-the opacity increased, but the enamels were lacking in gloss. The results obtained with Ro-2O and 2I were practically the same, the opacity being increased and gloss decreased. There was no apparent increase of opacity when antimony oxide was increased to more than 4 per cent, as in enamels Ro-22 and 23.

(e) REPLACEMENT OF FELDSPAR BY OXIDES OF ZIRCONIUM AND AnTimony.-Table $8 \mathrm{G}$ shows the effect of replacing feldspar by equal parts of zirconium and antimony oxides. The results obtained in this series were similar to those of the previous studies, where antimony and zirconium oxides were added separately; that is, the combination of the two oxides produced an increase of opacity and lack of gloss. Little difference could be noted when the contents of antimony and zirconium oxides were increased, as the texture and opacity of Ro-26 compared very closely to Ro-24, with the exception that the latter was slightly more fusible.

(f) REPLACEMENT OF FELDSPAR BY ZirRCONIUM Oxide AND CRYOLITE. - The results obtained by replacing feldspar by combinations of zirconium oxide and cryolite in the ratio of $\mathrm{I}$ to 3 , as in Table $8 \mathrm{H}$, were not very satisfactory, as crawling occurred in the resulting enamels. Small additions of the zirconia and cryolite appeared to promote crawling as much as the larger additions.

(g) REPLACEMENT OF FELDSPAR BY ANTIMONY OXIDE AND CRYOLITE.- The effect of replacing feldspar by combinations of antimony oxide and cryolite in the ratio of $\mathrm{x}$ to 3 is shown in Table 
$8 \mathrm{I}$. The results obtained in this series were similar to those of the preceding one. Crawling was apparent throughout the series.

(h) REPLACEMENT OF FELdSPAR AND SOdIUM OXIDE By FluORSPAR AND ANTIMONY OXIDE.-The effect of replacing feldspar and sodium oxide by fluorspar and antimony oxide is shown in Table $8 \mathrm{~J}$. In this study enamel Ro-8 was used as a basic composition. Increasing the fluorspar did not produce an increase of opacity. Crawling was produced when more than 3 per cent of fluorspar was added. When 2 per cent of sodium oxide was replaced by antimony oxide with the same compositions as in Ro-6, 35, and 36, the opacity was slightly increased, but the other properties of these enamels were very similar to those of Ro-33 and 34 .

(i) Additions of Tin Oxide to THE SMeiter Batch.-Table $8 \mathrm{~K}$ shows the effect of adding tin oxide to the smelter batch for compositions Ro-33 and 35, at the same time retaining the usual amount in the mill mix. Adding tin oxide tended to increase the opacity, but the development of pinholes and black specks was apparent. Practically the same results were obtained in Ro-33 as in Ro-35, and little difference could be noted as the content of tin oxide in the smelted batch was increased.

(j) RePlacement of BORIC OXIDE By CRyolite.-The effect of replacing boric oxide by cryolite is shown in Table $8 \mathrm{~L}$. The substitution of cryolite for boric acid resulted in better enamels than were obtained by the replacement of feldspar by cryolite. This resulted in a more workable enamel, and permitted the application of heavy coats without the development of crawling. A slight increase of opacity was apparent, and the enamel had an excellent gloss. The most satisfactory results were obtained with Ro-38, in which 4 per cent of boric oxide was replaced by cryolite.

(k) Additions of Zirconium Silicate to Enamels.-Table $8 \mathrm{M}$ shows the effect of adding various quantities of zirconium silicate to both the smelter batch and the mill mix in addition to the tin oxide. A good grade of zirconium silicate was used in making this study. These enamels showed a decided increase in refractoriness, but little improvement could be noted in opacity. The various contents of zirconium silicate were added to enamel Ro-38, which had given promising results. Enamel Ro-38a shows the effect of replacing the usual content of tin oxide in the mill mix by zirconium silicate, Ro- $38 \mathrm{~b}$ the effect of adding 4 per cent of zirconium silicate to the raw batch and retaining the usual mill mix, and Ro-38c the effect of adding 4 per cent of zirconium silicate to the raw batch and replacing the usual content of tin 
oxide in the mill mix by 4 per cent of zirconium silicate. Zirconium silicate added both to the raw batch and to the mill mix produced an increase in refractoriness, but an increase in opacity sufficient to warrant its use could not be noted.

TABLE 8 J.-Effect of Varying Feldspar, Fluorspar, Antimony, and Sodium Oxides in White Single-Coat Enamels.

[Constant portion melted, 18.56 $\mathrm{B}_{2} \mathrm{O}_{3}, 22.26 \mathrm{PbO}$.]

\begin{tabular}{|c|c|c|c|c|c|c|}
\hline \multirow{2}{*}{ Enamel number. } & \multicolumn{4}{|c|}{ Melted weights of variables. } & \multicolumn{2}{|l|}{ Results. } \\
\hline & Feldspar. & $\mathrm{CaF}_{2}$ & $\mathrm{Sb}_{2} \mathrm{O}_{3}$ & $\mathrm{Na}_{2} \mathrm{O}$ & Texture. & Opacity. \\
\hline 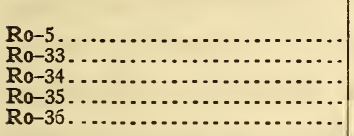 & \begin{tabular}{|r|} 
Per cent. \\
47.05 \\
41.05 \\
38.05 \\
41.05 \\
33.05
\end{tabular} & $\begin{array}{r}\text { Per cent. } \\
3.0 \\
6.0 \\
3.0 \\
6.0\end{array}$ & \begin{tabular}{r} 
Per cent. \\
\hdashline$\ldots$. \\
\hdashline \\
\hdashline$\ldots$. \\
2.0 \\
2.0 \\
\end{tabular} & $\begin{array}{r}\text { Per cent. } \\
12.13 \\
12.13 \\
12.13 \\
10.13 \\
10.13\end{array}$ & 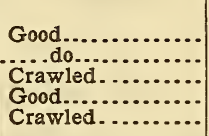 & $\begin{array}{l}\text { Poor. } \\
\text { Do. } \\
\text { Do. } \\
\text { Fair. } \\
\text { Do. }\end{array}$ \\
\hline
\end{tabular}

TABLE $8 \mathrm{~K}$.-Effect of Additions of Tin Oxide to the Smelter Batch of Enamels, Ro-33 and 35.

[Constant portions melted, Ro-33 and 35.]

\begin{tabular}{|c|c|c|c|}
\hline \multirow{2}{*}{ Enamel number. } & \multirow{2}{*}{ Amount of $\mathrm{SnO}_{2}$ added to batch. } & \multicolumn{2}{|l|}{ Results. } \\
\hline & & Texture. & Opacity. \\
\hline 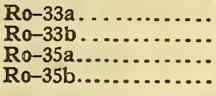 & 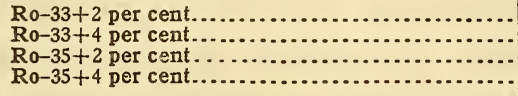 & $\begin{array}{l}\text { Few black specks...... } \\
\text { Pinholes ................ } \\
\text { Few black specks..... } \\
\text { Pinholes. }\end{array}$ & $\begin{array}{l}\text { Fair. } \\
\text { Do. } \\
\text { Do. } \\
\text { Do. }\end{array}$ \\
\hline
\end{tabular}

TABLE 8 L.-Effect of Varying Boric Oxide and Cryolite in Single-Coat White Enamels.

[Constant portion melted, 45.05 feldspar, $12.13 \mathrm{Na}_{2} \mathrm{O}, 22.26 \mathrm{PbO}, 2.0 \mathrm{Sb}_{2} \mathrm{O}_{3 .}$ ]

\begin{tabular}{|c|c|c|c|c|}
\hline \multirow{2}{*}{ Enamel number, } & \multicolumn{2}{|c|}{$\begin{array}{l}\text { Melted weights of } \\
\text { variables. }\end{array}$} & \multicolumn{2}{|c|}{ Results. } \\
\hline & $\mathrm{B}_{2} \mathrm{O}_{3}$ & Cryolite. & Texture. & Opacity. \\
\hline 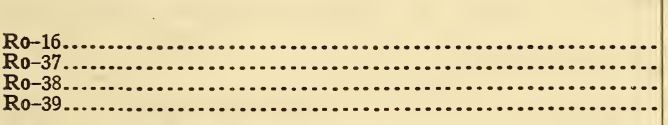 & \begin{tabular}{r|} 
Per cent. \\
18.56 \\
16.56 \\
14.56 \\
12.56
\end{tabular} & $\mid \begin{array}{r}\text { Per cent. } \\
2.0 \\
4.0 \\
6.0\end{array}$ & 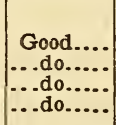 & $\begin{array}{c}\text { Fair. } \\
\text { Do. } \\
\text { Do. } \\
\text { Do. }\end{array}$ \\
\hline
\end{tabular}

TABLE $8 \mathrm{M}$.-Effect of Zirconium Silicate on Single-Coat White Enamel Ro-38.

[Constant portion, 45.05 feldspar, $14.56 \mathrm{~B}_{2} \mathrm{O}_{3}, 12.13 \mathrm{Na}_{2} \mathrm{O}, 22.26 \mathrm{PbO}, 2 \mathrm{Sb}_{2} \mathrm{O}_{3}, 4$ cryolite.]

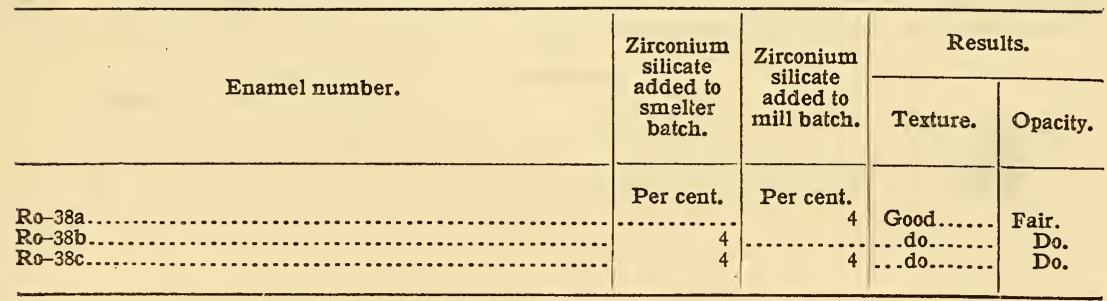




\section{CONCLUSIONS FROM STUDY OF SINGLE-COAT WHITE ENAMELS.}

In the production of white single-coat enamels it was necessary to develop maximum opacity in the frit, since the addition of more than 3 to 4 per cent of tin oxide in the mill batch caused blistering of the enamels. The latter defect was undoubtedly due to the reduction of tin oxide when in contact with the iron during the firing process. This defect also developed if additional tin oxide beyond the 3 to 4 per cent added in the mill was mixed with the smelter batch.

The ordinary secondary opacifying agents, such as fluorspar, cryolite, antimony oxide, and zinc oxides, while imparting some opacity did not prove satisfactory in other respects. Cryolite, fluorspar, and zinc oxide tended to cause crawling, while antimony oxide decreased the gloss considerably. The latter difficulty was also encountered with zirconium oxide and silicate. The zirconium compounds decidedly increased the refractoriness of the enamels. Suitable mill additions for enamels of this type are the following: Frit Ioo, clay 4, tin oxide 4, and water 45 .

The most satisfactory compositions were Ro-r6, in which antimony oxide was introduced, and Ro-38, in which some of the boric oxide of the basic composition was replaced by cryolite. In no case, however, were these compositions equal in opacity to the white enamels applied over a ground coat as developed in Part I of this paper. The following enamels are typical of those giving best results:

Single-Coat White Enamels.

\begin{tabular}{|c|c|c|}
\hline Material. & \multicolumn{2}{|c|}{$\begin{array}{l}\text { Batch composition } \\
\text { of frits. }\end{array}$} \\
\hline & Ro-16. & Ro-38. \\
\hline 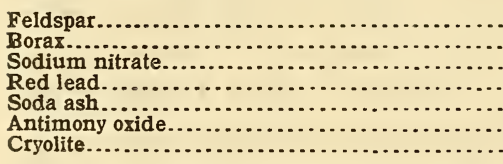 & $\begin{array}{r}45.05 \\
50.57 \\
4.63 \\
22.71 \\
3.85 \\
2.00 \\
\end{array}$ & $\begin{array}{r}45.05 \\
39.67 \\
4.63 \\
22.71 \\
6.87 \\
2.00 \\
4.00\end{array}$ \\
\hline
\end{tabular}




\section{SUMMARY.}

The conclusions from this investigation are based on the results obtained in the application of 132 enamels to approximately 900 castings in this laboratory. About 600 trials were used in the study of white ennamels with the use of a ground coat and I50 each for the colored and white single-coat enamels. In addition, some of our laboratory results on the most promising enamels were checked at the plant of the A. J. Lindemann \& Hoverson Stove Co. In this part of the work, conducted under regular factory conditions, I5 of the enamels were prepared in full-size commercial batches and applied to about 325 stove castings, such as oven and broiler doors, pouch-feed frames, fire-door panels, main fronts, oven-burner plates, fiue doors, and brackets. The results of the factory tests have been considered in the final preparation of this report.

The investigation has resulted in the development of a number of satisfactory compositions for the enameling of cast iron by the wet process. A suitable technic in the preparation and application of the enamels, which is always of great importance, has been developed and has been discussed in this report in the conclusion to Part I and Part II.

While colored enamels of a single-coat type are easily produced, the results of this investigation would indicate that it is possible to produce white enamels over a ground coat with a more satisfactory texture and opacity than is possible in enamels to be applied directly to the iron.

The writers wish to express their appreciation of the cooperation of W. C. Lindemann in furnishing the castings used in this investigation and in placing at our disposal the equipment of the enameling department of the A. J. Lindemann \& Hoverson Stove Co. for the purpose of checking our results on a factory scale. Thanks are extended to Evadne Saeger for assistance in preparing the large number of test specimens involved in the investigation.

WASHINGTON, May 24, 1923. 